\title{
The impact of sectoral minimum wage laws on employment, wages, and hours of work in South Africa
}

\author{
Haroon Bhorat, Ravi Kanbur and Natasha Mayet
}

\author{
* Correspondence: haroon.bhorat@ \\ uct.ac.za \\ School of Economics, University of \\ Cape Town; The Charles H. Dyson \\ School of Applied Economics and \\ Management and Department of \\ Economics, Cornell University, and \\ School of Economics, University of \\ Cape Town
}

\begin{abstract}
This paper attempts to investigate the impact of sectoral wage laws in South Africa. Specifically, we examine the impact of minimum wage laws promulgated in the Retail, Domestic work, Forestry, Security, and Taxi sectors using 15 waves of biannual Labour Force Survey data for the 2000-2007 period. Using a quasi-experimental approach, we apply two alternative specifications of a difference-in-differences model to estimate the impact of multiple minimum wage laws in South Africa on employment, wages, and hours of work. In order to assess whether the changes experienced by workers in the sectors analysed were unique to those sectors, a unique control group is identified for each sector. We find some evidence of a significant increase in real hourly wages in the post-law period in four of the five sectors examined. Our results also suggest that whilst there was no significant impact of the laws at the extensive margin, there was some evidence of an adjustment at the intensive margin in certain sectors. We also find that in three of the five sectors, increases in real hourly wages were sufficient to outweigh intensive margin adjustments so that workers in these sectors experienced an improvement in real monthly income as a result of the law.

JEL codes: C21, J23, J30, J31, J38.
\end{abstract}

Keywords: Minimum wage, South Africa, Wage, Employment, Hours of work

\section{Introduction}

The aim of this paper is to investigate how employers in a low wage sector of the labour market respond to the introduction of a minimum wage. The standard textbook model of minimum wages predicts that in a competitive equilibrium, there is a negative relationship between minimum wages and employment. However, a growing number of studies indicate that the relationship between the minimum wage and employment is not necessarily always negative (Katz and Krueger 1992; Card, 1992a, b).

The international debate on minimum wages began even before minimum wages were first introduced in the United States at 25 cents per hour in $1938^{1}$. The relationship between minimum wages and labour market outcomes is a relatively recent debate in South Africa by international standards. Whilst the international literature on minimum wages dates as far back as the theoretical works of economists such as Stigler (1946) and Lester (1947), leading into the new minimum wage research (Card, 1992; Card and Krueger 1994, 1995; Neumark and Wascher 1992), the literature on minimum wages in South 
Africa is relatively recent. This may be explained by the fact that minimum wages in South Africa have a fairly short history compared with other comparator countries ${ }^{2}$.

The introduction of minimum wages in 1999 in the Contract Cleaning sector was followed by sectoral minima for the Civil Engineering and Private Security sectors in 2001. Since then, a few studies have been conducted in South Africa which explore the effects of the minimum wage on employment, hours worked and other labour market outcomes, as well as the impact of minimum wages on household poverty (Hertz 2002a, 2002b, 2005; Bhorat, 2000; Dinkelman and Ranchhod, 2012). These studies tend to focus on a single sector, such as the Farm or the Domestic worker sectors, which are of course traditionally low-wage employee sectors. Hertz (2005) concludes that employment changes experienced by Domestic workers since the introduction of the sectoral minimum wage were no different to workers in other sectors. A more recent study by Dinkelman and Ranchhod (2012) found that the probability of employment of a typical Domestic worker was unchanged after the introduction of minimum wage laws. No empirical attempt has been made this far however, to investigate the impact of minimum wages on the other covered sectors in South Africa. This is perhaps due to the complex nature of the minimum wage laws in South Africa, with multiple minimum wages that differ by sector, occupation and often by location of employment that make it difficult to allocate wages to individual workers in the household survey data.

This paper attempts to address this gap in the literature by providing an analysis of the impact of these multiple minimum wages on the wages, employment and hours worked of affected workers in South Africa. In doing so, this study constitutes the first attempt to investigate the impact of minimum wages in South Africa in sectors other than the Farm and Domestic worker sectors, and provides a more complete picture of the labour market impact of the country's multiple minimum wage laws.

\section{Evidence on the impact of minimum wages}

Early studies on the effect of the minimum wage on employment, dating as far back as the work of Stigler (1946), predicted that in a competitive labour market, the relationship between minimum wages and employment is a negative one. A number of studies on the effects of the minimum wage on teenage employment also confirmed this result (Brown et al. 1982; Charles et al. 1983), although later evidence suggested that whilst the employment impact was negative, the effect was small, with a 10 percent increase in the minimum resulting in a reduction in teenage employment of less than 1 percent. On the other hand, earlier studies such as Lester $(1960,1967)$ found no negative employment effect associated with the legislated minimum.

The 1990s saw the beginning of a new stream of literature on minimum wages, known as the 'new minimum wage' literature. The results from this literature suggest that the textbook argument of a trade-off between minimum wages and employment does not necessarily hold (Katz and Krueger 1992; Card, 1992a, b; Machin and Manning, 1994). In their seminal work, Card and Krueger (1994) presented new evidence on the effect of minimum wages on employment, finding no disemployment effects from the mandated minima. Neumark and Wascher (2007) in their review of the recent minimum wage literature, conclude that whilst a few studies do find positive effects associated with the minimum wage, the majority of studies suggest a negative impact, particularly when the effects of minimum wages are analysed in the aggregate as opposed to within a specific sector. 
As a counterpoint to the literature on the impact of minimum wages using US data, studies on the effects of minimum wages using non-U.S. data are sparse ${ }^{3}$. This is particularly the case for studies on the effects of minimum wages in developing countries. This is somewhat surprising, given that developing countries provide an interesting context for the analysis of minimum wage effects due to the often larger exogenous variation in the minimum wage in these countries (Hamermesh, 1993, 2002).

A recent study by Gindling and Terrell $(2005,2007)$ investigated the employment effects of an increase in minimum wages in Costa Rica over the 1988 to 2000 period. Their results suggest that a 10 percent increase in the minimum wage results in a decline in employment and hours worked in the covered sector of around 1.09 percent and 0.6 percent respectively. They find that the impact of the minimum wage in Costa Rica is the largest for unskilled workers, and conclude that those individuals rendered unemployed in the covered sector enter the uncovered sector. However, their results do not show any significant impact at the intensive margin in the uncovered sector.

Since the introduction of the first sectoral minimum wage (Contract Cleaners in 19994) in South Africa, there have been a few studies that have considered the impact of minimum wage laws in the country. However, these studies have mostly focused on the effects of the law in a specific sector. In particular, the sectoral minima in the Farm and Domestic worker sectors have received attention in this respect. Bhorat (2000) showed that minimum wage hikes in South Africa are associated with a decline in employment among low-paid Farm and Domestic workers. Hertz (2005) analysed the impact of minimum wages on employment and earnings of Domestic workers in South Africa, finding that whilst minimum wages were associated with a rise in average monthly and total earnings, there were significant disemployment effects resulting from the laws. In the Agricultural sector, Conradie (2004) found negative employment effects of between 3 and 6 percent associated with a $10 \%$ rise in the minimum wage for a sample of 190 grape farmers in the Western Cape. Another case study was conducted by Murray and Van Walbeek (2007) on a sample of 103 Farm workers in the sugar industry. Their results showed that whilst no large disemployment effects occurred, there was some indication that employers substituted at the lower skills margin as well as adjusted at the intensive margin of labour to reduce weekly wage costs. Dinkelman and Ranchhod (2012) used a difference-indifferences approach to investigate the impact of minimum wages in the Domestic worker sector. They conditioned their sample on urban Domestic workers employed over the 2001-2004 period, finding no significant changes in employment on the intensive or the extensive margins for Domestic workers. Bhorat, Kanbur and Stanwix (2011) used a similar approach to analyse the impact of introducing a minimum wage in the Agricultural sector for South Africa. Using data for the 2000-2007 period they showed that whilst there were significant negative effects associated with the minimum on the extensive margin, the effects on the intensive margin were insignificant. There has however, been very little research on the impact of minimum wage laws in other sectors in South Africa.

\section{Data and econometric approach}

\subsection{The South African labour force survey}

The dataset used is a pooled dataset consisting of 15 waves of the South African Labour Force Survey (LFS) from 2000 to 2007. The LFS is a nationally representative household 
survey that was conducted biannually on the basis of a rotating panel by Statistics South Africa (StatsSA) between 2000 and 2007 during February/March and September. The survey includes around 30,000 households in both urban and rural areas in South Africa. Information in the LFS is self-reported. In 2008, the LFS was replaced with the Quarterly Labour Force Survey (QLFS). However, the QLFS does not provide any information on wages and the September 2007 LFS remains the last nationally representative survey that contains wage information. All 15 waves were pooled and are treated as repeated crosssections over time.

The South African Department of Labour minimum wage laws specifically identify the groups of individuals to whom the laws apply. In each wave of the LFS, minimum wage workers were therefore identified using the overlap of both the four digit SASCO occupation codes and the three digit ISIC industry codes. Any workers to whom the law did not apply, notably the self-employed who pay their own wages, were excluded from the analysis. We also restricted the sample to non-government employees. Estimates presented are weighted ${ }^{5}$ estimates.

\subsection{Sample selection and key variables}

The South African Department of Labour has introduced minimum wage laws in $11 \mathrm{sec}-$ tors $^{6}$. These minima are regularly updated for inflation using a formal gazetting process ${ }^{7}$. However, it is only possible to identify nine of these sectors using the LFS data ${ }^{8}$. The following five sectors were included in the analysis: Retail, Domestic workers, Forestry, Taxi workers, and Private Security. For the Contract Cleaning (introduced in 1999) and the Hospitality sectors (introduced in 2007) no dataset for the pre- and post-law periods was available, respectively ${ }^{9}$. The Civil Engineering sector was not included since the use of the four-digit occupational codes in the LFS yielded a very small number of Civil Engineers for the datasets in the pre-law period (the September 2000 and February 2001 datasets, which are the only datasets for the period prior to the introduction of the law in March 2001, yield only 12 and 11 observations respectively $)^{10}$. As the impact of minimum wages on the Agricultural sector was already investigated by Bhorat, Kanbur and Stanwix (2011), we restricted our analysis to the five sectors listed above. These sectors accounted for 17.2 percent of non-agricultural employment in September 2007 (approximately 2.2 million individuals). Taken together with the Agricultural sector then, the sectors covered here accounted for around 76 percent of the sample of minimum wage workers in the September 2007 Labour Force Survey.

In order to analyse whether the changes experienced within each sector were unique to those workers in that sector to whom the law applied, we used a unique control group for each of the minimum wage sectors that are the treatment groups in the analysis. For each sector, we identified a control group consisting of workers with similar characteristics to the affected sector, and who are not expected to be affected by the minimum wage. All control groups were restricted to low-income earning individuals (individuals earning less than R10,000 per month), who were aged between 15 and 65 years, and who had completed no more than 12 years of schooling. Furthermore, union members, self-employed workers, government workers and part-time workers were excluded from the control groups, as well as workers who were affected by another minimum wage law. Additionally, the individual characteristics of workers in 
each sector as well as the four-digit occupational codes in the survey were used, in order to construct a control group with similar characteristics to the sector.

The control group for Domestic workers was restricted to African and Coloured females who were employed in unskilled occupations (mainly elementary workers for whom no minimum wage is set). The control group for the Forestry sector included only African and Coloured individuals in unskilled employment. The control group for the Retail sector included individuals in semi-skilled occupations only. Finally, for the Security and Taxi sectors, the same control group was used, specifically African and Coloured males employed in similar semi-skilled occupations ${ }^{11}$. Mean characteristics of the different treatment and control groups for the different sectors are presented in Table 1 and are discussed in more detail in Section 4 of the paper.

For the analysis of the impact of minimum wages on employment, we used a broader control group consisting of individuals of working age who were either employed or seeking work (narrow labour force) and who had completed no more than 12 years of schooling ${ }^{12}$. Workers who lose their jobs in the minimum wage affected sector may find another job or become unemployed. This specification of a broader control group therefore allows for individuals whom may have been rendered unemployed, or who switched jobs between waves, to be accounted for. The control group in the employment equations for each of the five minimum wage sectors examined therefore includes workers employed in other sectors (This includes workers employed in other minimum wage affected sectors $)^{13}$.

Table 1 Mean sample characteristics of sector and control groups in the pre-law period (March and September waves)

\begin{tabular}{llllll}
\hline Minimum wage sector (Treatment group) & Retail & Domestic Workers & Forestry & Taxi & Security \\
\hline African & $0.57^{*}$ & $0.90^{*}$ & $0.98^{*}$ & $0.96^{*}$ & 0.84 \\
Male & $0.51^{*}$ & 0.04 & $0.66^{*}$ & 0.97 & 0.89 \\
Age & $34.1^{*}$ & $39.6^{*}$ & $35.5^{*}$ & 34.8 & $33.0^{*}$ \\
Years of schooling & $10.4^{*}$ & $6.1^{*}$ & $5.3^{*}$ & $8.9^{*}$ & $10.0^{*}$ \\
Area A/Metropolitan area & 0.82 & 0.78 & $0.47^{*}$ & 0.79 & 0.86 \\
Wage Gap & 0.70 & 0.91 & 0.73 & 0.31 & 0.74 \\
Control groups & Retail & Domestic Workers & Forestry & Taxi & Security \\
African & 0.67 & 0.77 & 0.84 & 0.89 & 0.89 \\
Male & 0.71 & 0 & 0.72 & 1 & 1 \\
Age & 36 & 34.2 & 33.4 & 35.7 & 35.7 \\
Years of schooling & 8.5 & 7.6 & 8.1 & 8.4 & 7.9 \\
Area A/Metropolitan area & 0.82 & 0.77 & 0.80 & 0.82 & 0.82 \\
F-statistic & $395.0^{* * *}$ & $116.6^{* * *}$ & $26.5^{* * *}$ & $293.7^{* * *}$ & $50.2^{* * *}$
\end{tabular}

Source: Data are from South African Labour Force Surveys (LFS) (September and March waves) conducted by Statistics South Africa.

Note: Estimates are weighted means for the pooled dataset that includes both September and March waves for the pre-law period in each sector. Sample includes non self-employed, non-government workers only aged between 15 and 65 years inclusive. All control groups were restricted to non self-employed, non-government and non-unionized workers who were not in sectors affected by minimum wage laws. Where relevant, a test for the equality of means between the treatment and the control group was performed. An asterisk indicates that the null hypothesis for the equality of means of the treatment and the control group was rejected at the 5 percent level. The F-statistic uses a Hotelling's test for the joint equality of the means of the set of demographic variables between each respective treatment and control group in the pre-law period. The Null hypothesis assumes the joint equality of means of all demographic variables across each treatment/control group for each sector and is rejected at the $1 \%$ level for each treatment and control group comparison. 
Although the process of matching each of the minimum wage sectors (treatment groups) to their respective control groups attempted to derive a control group comprised of individuals with characteristics as similar as possible to the sector, it is important to explicitly acknowledge the limitations of such an identification strategy. This is particularly so because, as noted in the literature review above, spillover effects from covered sectors to uncovered sectors may occur due to minimum wage affected workers who are rendered unemployed finding employment in other sectors (Gindling and Terrell 2005, 2007). Such effects are difficult to detect and measure. For example, individuals in the control groups may experience a negative effect on wages due to workers in minimum wage affected sector losing their jobs and finding employment in other sectors. Therefore, the estimates of the impact of minimum wage laws on employment, wages, and hours of work respectively may be biased upwards (that is, we may overestimate the impact of the legislation on the treatment sector). Therefore, as explained in the section below, we include a second difference-in-differences specification that does not involve using a control group. This is the preferred specification unless stated otherwise.

Individuals in each wave of the LFS were mapped to the relevant published minima. This was done using a detailed mapping of individuals to the respective minimum wage sector using the four-digit occupational and the three-digit industrial coding provided with the LFS ${ }^{14}$. Since the minimum wages are set according to area for some of the sectors, the geographical units in the LFS (magisterial districts before 2004 and district councils from 2005 onwards) were matched to the area types A, B, C, etc. specified by the sectoral minima ${ }^{15}$. Hourly minima were used. Minima were then assigned to the individuals in the LFS data to whom the sectoral laws applied. The relevant sample of minimum wage workers was assumed to be non-governmental workers who were not self-employed.

Workers may provide wage information in the LFS as either point estimates or in monthly brackets. Estimates provided as brackets were converted to point estimates by random allocation within their respective brackets using a uniform distribution. On average, the percentage of workers covered by minimum wage laws who reported their income in bands fluctuates between 12 and 16 percent from one wave to another ${ }^{16}$. Monthly wages were then combined and converted into hourly wages using the average number of weekly hours worked by an individual. To obtain real wages, wages were deflated to constant 2000 prices using the Consumer Price Index (CPIX) provided by Statistics South Africa.

Only working-age individuals were included in the sample, that is, individuals between 15 and 65 years of age. Any individuals who reported working more than 15 hours per day were not included in the sample of workers in the analysis. In addition, any individuals reporting zero or missing wages are excluded from the sample. We also selected out the top 1 percent of earners in each sector as workers earning very high wages are not assumed to be affected by minimum wage laws. The sample included workers in all district councils, that is, both rural and urban areas. Full-time individuals we redefined as those who work at least 27 hours per week. The regression analysis was limited to full-time workers only.

It is worth noting that one of the limitations of the wage data in the LFS is that no information is provided about payment in kind. The legislation specifies that the total 
remuneration due to an employee is the total of the money paid and the payment in kind. For the case of Domestic workers, the legislation specifies that this may not exceed 10 percent of the wage for accommodation provided. Since we were only able to measure wage income paid by an employer, there is a possibility that increases in wages observed in the post-law period may simply be a reflection of the reallocation of non-wage benefits provided by employers in order to pay higher wages.

\subsection{Estimation strategy}

We apply the classic Card and Krueger model (1995) to the data. Two alternate specifications are used:

$$
\begin{aligned}
& Y_{i j k t}=\beta_{0}+\beta_{1} \text { Post }_{t}+\beta_{2} \text { Sector }_{k}+\beta_{3} \text { Post }_{t} * \text { Sector }_{k}+\phi_{j}+\varepsilon_{i j k t} \\
& Y_{i j k t}=\alpha_{0}+\alpha_{1} \text { Post }+a_{2} \text { Gap }_{j k}+a_{3} \text { Post }_{t} * \text { Gap }_{j k}+\chi_{i j k t}+\gamma_{i j k t}
\end{aligned}
$$

In equation (1) $Y_{i k t}$ is the outcome of interest (e.g. employment, wages, hours worked, etc.) for individual $i$ in group $k$, district council $j$ and period $t$. Post $t_{t}$. is a time dummy measuring pre-law and post-law effects. This variable is set equal to 0 for all periods prior to the introduction of minimum wage laws in a sector, and 1 for all periods following the introduction of the sectoral minima. We assume that the timing of the introduction of a law is the date that the law became effective/binding in the published legislation ${ }^{17}$. Sector ${ }_{k}$ is a dummy variable equal to 1 if the individual is employed in the sector affected by the minimum wage (treatment group) and 0 if the individual is in the control group. Post ${ }_{t}{ }^{*}$ Sector $_{k}$ is the difference-in-differences term capturing the average treatment effect. This term tests for whether or not the observed changes were shared by similar groups of workers to whom the law did not apply, confirming that the results observed were not the result of economy-wide shocks. The coefficient $\beta_{1}$ on the Post variable measures the average change in the post-law period in the outcome variable for both the treatment and the control groups. The coefficient $\beta_{2}$ on the Sector $k_{k}$ variable measures the average difference in the outcome variable $Y_{i k t}$ between the treatment and the control group in the full period. The coefficient $\beta_{3}$ on the difference-in differences term is the key measure in this specification, showing the change in the measured outcome for the treatment sector in the post-law period relative to the control group ${ }^{18}$.

It is worth noting that the specification in equation (1) includes the control and the treatment group only. Since the control group selected has similar characteristics to the treatment group, no individual level controls are included. The equation was estimated with and without district level controls $\phi_{j}$. Under the hypothesis of a natural experiment where we have two similar groups and a clear distinction between treated and non-treated, we assume that in the absence of a minimum wage law the same general trend would be observed for both groups of workers (Employment trends in the treatment and their respective control groups are presented in Figure 1).

Equation (1) is run only on the individuals employed in that particular sector; that is, the treatment group. $\chi_{i j k t}$ are controls for various worker characteristics such as years of schooling, age, race and gender. Using examples in the minimum wage impact literature (Card and Krueger, 1995; Lee, 1999) we construct a relative measure of the variation across district councils in the intensity of the introduced minimum $\left(\operatorname{Gap}_{j k}\right)$ based 


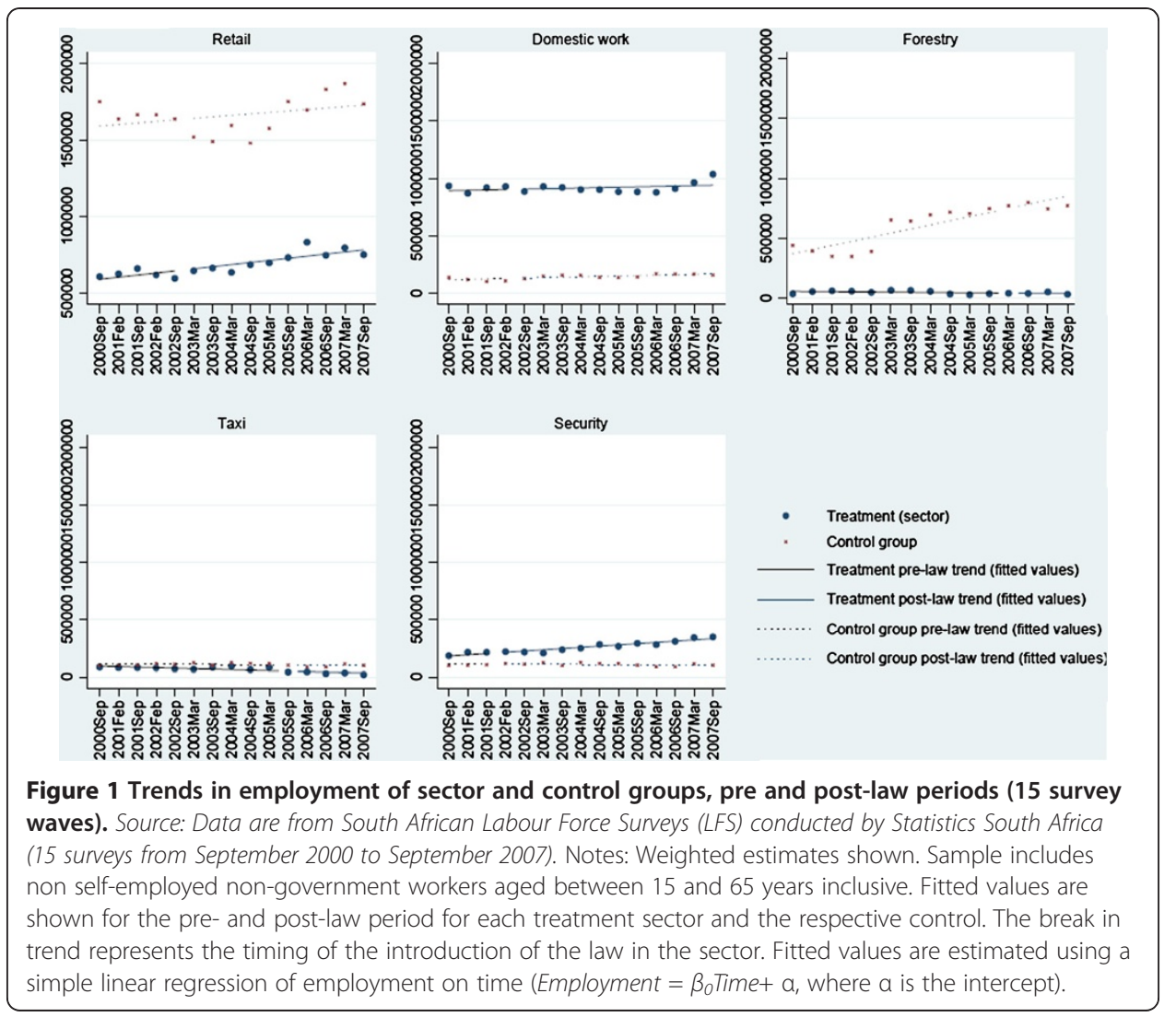

on the initial wage of workers in the pre-law period. The Gap $p_{j k}$ variable included in equation (2) attempts to capture the intensity of the impact of the minimum wage in a sector $k$ in district council $j^{19}$ and is constructed as follows:

$$
\operatorname{Gap}_{j k}=\left(w_{m j k}^{t}-w_{j k}^{t-1}\right) / w_{j k}^{t-1} \text { where } \operatorname{Gap}_{j k} \geq 0
$$

where $w_{m k j}^{t}$ is the original minimum wage in sector $k$ and district council $j$ at time $t$, the first year when the minimum wage was introduced in the respective sector, and $w_{k j}^{t-1}$ is the initial average wage in sector $k$ in district council $j$ in the year prior to the introduction of the law. The $\operatorname{Gap}_{j k}$ measure is set at 0 for districts where the average wage in the sector is greater than the minimum introduced. We construct the Gap ${ }_{j k}$ measure using real, full-time hourly wages ${ }^{20}$. Summary statistics of this measure are presented in Table 1.

The $\operatorname{Gap}_{j k}$ variable provides a measure of the proportional increase in the initial wage that is necessary to meet the minimum wage and provides a measure of the spatial variation in the intensity of the law's impact. The variation in the Gap ${ }_{j k}$ measure captures the regional differences based on the reported wages of workers in the pre-law period ${ }^{21}$. The parameter $a_{2}$ measures the average difference in outcomes of workers in low prelaw wage gap versus high pre-law wage gap district councils in the period subsequent to the introduction of the law. The difference-in-differences parameter $a_{3}$ measures the change in $Y_{i k t}$ attributable to the minimum wage in the post-law period in district councils where the Gap ${ }_{j k}$ measure was the largest, that is, where the intensity of the 
minimum wage was higher. Lastly, $a_{1}$ tells us how the variable of interest changed on average in the post-law period.

\section{Descriptive statistics}

Table 2 presents the five different sectoral minima included in the analysis along with the different categories within each legislation and the year and month of introduction of the law ${ }^{22}$. The minimum wage legislation for the Retail and Wholesale sector came into effect in February 2003. The minimum wages for this sector are the most complex, with several different minima specified according to occupation, hours worked and area type. Using the LFS sector and occupation codes, it was possible to identify the following groups of workers within the sector: Managers, clerks, shop assistants, sales assistants, cashiers, drivers, security guards and fork-lift operators. Within each of these occupational categories, different minima are specified for areas $\mathrm{A}, \mathrm{B}$, and $\mathrm{C}^{23}$, as well as in some years by firm size and for full-time and part-time employees respectively, resulting in over 24 different categories of minima for the workers in this sector.

The sectoral minima for Domestic workers were introduced in August 2002. Within this legislation, there are two area types, $\mathrm{A}$ and $\mathrm{B}$. The prescribed minima differ on the basis of whether or not the number of hours worked is below or above 27 hours per week (part-time and full-time employees respectively).

The sectoral minimum for the Forestry sector was introduced in March 2006. Therefore, three waves of the LFS (September 2006, March 2007 and September 2007 respectively) are available for analysis of the post-law period for this sector. The legislation sets a fixed minimum rate of remuneration for those working in all areas within the Forestry sector, with no locational differential.

The sectoral minima for the Taxi sector were introduced in July 2005 and apply to all workers in the transport sector involved in the operation of informal minibus taxis. Within this legislation a distinction is made between taxi drivers and fare collectors ${ }^{24}$.

Table 2 Sectoral minima and date of introduction

\begin{tabular}{|c|c|c|c|c|c|}
\hline Sector & Occupation & Areas & Full-time/Part-time & Firm size & Date \\
\hline \multirow[t]{7}{*}{ Retail } & Managers & $\begin{array}{l}A, B \text {, and } \\
C\end{array}$ & $>27$ hours per week & $\begin{array}{l}<5 \\
\text { employees }\end{array}$ & $\begin{array}{l}\text { February } \\
2003\end{array}$ \\
\hline & Clerks & & $\leq 27$ hours per week $^{1}$ & $\geq 5$ & \\
\hline & Sales Assistant & & & employees ${ }^{2}$ & \\
\hline & Shop assistant & & & & \\
\hline & Drivers & & & & \\
\hline & Forklift operators & & & & \\
\hline & Cashiers & & & & \\
\hline $\begin{array}{l}\text { Domestic } \\
\text { work }\end{array}$ & $\mathrm{N} / \mathrm{A}$ & $A$ and $B$ & $\begin{array}{l}>27 \text { hours per week } \leq 27 \text { hours } \\
\text { per week }\end{array}$ & N/A & August 2003 \\
\hline Forestry & $\mathrm{N} / \mathrm{A}$ & N/A & N/A & N/A & March 2006 \\
\hline Taxi workers & $\begin{array}{l}\text { Drivers Fare } \\
\text { collectors }\end{array}$ & N/A & N/A & N/A & July 2005 \\
\hline $\begin{array}{l}\text { Private } \\
\text { Security }\end{array}$ & N/A & $\begin{array}{l}1,2,3,4 \\
\text { and } 5\end{array}$ & N/A & N/A & $\begin{array}{l}\text { November } \\
2001\end{array}$ \\
\hline
\end{tabular}

Source: Government Gazettes available from <http://www.labour.gov.za>. Notes: ${ }^{1}$ Since 2006.

2 Until 2005. 
The minimum wage laws for the Private Security sector were introduced in November 2001 and apply to all employers and employees involved in guarding or protecting fixed property, premises, goods, persons or employees (Note that Security workers in the Retail sector are covered by the sectoral minima for Retail sector workers). There are five different area types specified within this sector, numbered from 1 (or type A areas) through 5 respectively.

Table 1 presents the mean sample characteristics for the sectors included in the analysis across all waves in the pre-law period, along with those of their identified control groups. Each sector is characterized by unique sample characteristics, which made it necessary to specify a unique control group of similar workers for each sector. Workers covered by the sectoral minima generally possess no higher than a Matric education (12 years of schooling). Therefore, as described earlier, during the construction of the control groups, the sample was restricted to employees with less than 12 years of schooling. In each of the sectors, the majority of workers are located in areas which were classified as either type A areas or metropolitan areas (over 70 percent), with the exception of the Forestry sector.

Relative to the other sectors examined here, workers within the Retail sector have on average completed higher levels of education. The average worker in this sector has completed around ten years of schooling, which is high relative to the other sectors represented here. The Domestic worker sector is comprised almost entirely of African and Coloured unskilled females with low levels of schooling. This sector is generally concentrated in urban households (78 percent). Within the Forestry sector, the dominant share of workers is African and male (98 percent and 66 percent respectively). These individuals generally have low levels of schooling (around 5 years of schooling for the average worker). Workers in the Security and Taxi sectors are most likely to be African and male with less than 12 years of schooling. The dominant share of workers in these two sectors were located in areas classified as A or metropolitan areas. It is worth noting that the same control group was identified for the Taxi and the Security sectors, namely African and Coloured males engaged in similar (semi-skilled) occupations and who possessed fewer than 12 years of schooling.

In order to shed some light on the trends in employment in the period prior to and following the introduction of the law, Figure 1 examines the changes in employment for the five sectors and their respective control groups during the pre-law and the post-law periods. The descriptive evidence does not indicate a significant decline in employment in the post-law period for most of the sectors shown. Indeed, the estimates suggest that the Security sector experienced an increase in employment in the post-law period. The only sector where we see a significant decline in employment is within the Taxi sector. The remaining sectors do not indicate a statistically significant change in employment in the post-law period. For the control groups, employment generally increased or remained stable in the post-law period. Overall then, the early evidence presented here does not suggest a significant negative impact on employment of minimum wage laws for the five sectors examined.

Table 3 presents the mean characteristics of employed workers for the five sectors and their respective control groups. The majority of workers are full-time workers for all cohorts. Examining the changes in the share of full-time workers across time, a significant increase is observed for the Retail, Domestic worker and Security sectors in 
Table 3 Mean characteristics of employed sample (2000 to 2007), treatment and control groups

\begin{tabular}{|c|c|c|c|c|c|c|c|c|c|c|c|c|}
\hline & & 2000 & 2001 & 2002 & 2003 & 2004 & 2005 & 2006 & 2007 & $\begin{array}{c}\text { Mean } \\
\text { Pre- } \\
\text { law }\end{array}$ & $\begin{array}{c}\text { Mean } \\
\text { Post- } \\
\text { law }\end{array}$ & $\begin{array}{l}\text { Pre-post } \\
\text { difference }\end{array}$ \\
\hline \multirow[t]{4}{*}{ Retail } & Fulltime & 0.92 & 0.94 & $0.95^{*}$ & $0.94^{*}$ & $0.96^{*}$ & $0.96^{*}$ & $0.96^{*}$ & $0.96^{*}$ & 0.94 & 0.96 & $0.02^{*}$ \\
\hline & $\begin{array}{l}\text { Hours per } \\
\text { Week }\end{array}$ & 47.3 & 48.5 & 48.5 & 47.7 & 47.5 & 48.5 & 46.8 & 46.3 & 48.3 & 47.3 & $-1.0^{*}$ \\
\hline & $\begin{array}{l}\text { Nominal } \\
\text { Hourly } \\
\text { Wage }\end{array}$ & 10.8 & 10.4 & 11.1 & 12.6 & $13.9^{*}$ & $14.0^{*}$ & $15.1^{*}$ & $15.6^{*}$ & 10.8 & 14.3 & $3.5^{*}$ \\
\hline & $\begin{array}{l}\text { Real hourly } \\
\text { wage }\end{array}$ & 10.7 & 9.9 & 9.6 & 10.0 & 10.9 & 10.7 & 11.0 & 10.6 & 9.9 & 10.7 & $0.8^{*}$ \\
\hline \multirow[t]{4}{*}{ Control } & Fulltime & 0.92 & $0.95^{*}$ & $0.94^{*}$ & $0.96^{*}$ & $0.97^{*}$ & $0.96^{*}$ & $0.96^{*}$ & $0.97^{*}$ & 0.94 & 0.97 & $0.03^{*}$ \\
\hline & $\begin{array}{l}\text { Hours per } \\
\text { Week }\end{array}$ & 45.5 & 46.3 & 45.9 & 45.7 & 45.9 & $47.5^{*}$ & 46.3 & 46.1 & 46.0 & 46.3 & 0.3 \\
\hline & $\begin{array}{l}\text { Nominal } \\
\text { Hourly } \\
\text { Wage }\end{array}$ & 9.5 & 9.8 & $10.6^{*}$ & $12.0^{*}$ & $12.4^{*}$ & $12.0^{*}$ & $13.1^{*}$ & $14.4^{*}$ & 10.0 & 12.8 & $2.8^{*}$ \\
\hline & $\begin{array}{l}\text { Real hourly } \\
\text { wage }\end{array}$ & 9.3 & 9.3 & 9.1 & 9.6 & 9.7 & 9.2 & 9.6 & 9.8 & 9.2 & 9.6 & 0.4 \\
\hline \multirow{4}{*}{$\begin{array}{l}\text { Domestic } \\
\text { work }\end{array}$} & Fulltime & 0.81 & 0.84 & 0.83 & 0.82 & 0.82 & 0.79 & 0.79 & 0.81 & 0.83 & 0.81 & $-0.02^{*}$ \\
\hline & $\begin{array}{l}\text { Hours per } \\
\text { Week }\end{array}$ & 41.3 & 42.3 & 42.5 & 40.8 & 40.4 & 41.8 & 39.1 & 39.2 & 42.2 & 40.4 & $-1.8^{*}$ \\
\hline & $\begin{array}{l}\text { Nominal } \\
\text { Hourly } \\
\text { Wage }\end{array}$ & 2.8 & 2.9 & 2.7 & $3.3^{*}$ & $4.0^{*}$ & $4.0^{*}$ & $4.8^{*}$ & $5.5^{*}$ & 2.8 & 4.2 & $1.4^{*}$ \\
\hline & $\begin{array}{l}\text { Real hourly } \\
\text { wage }\end{array}$ & 2.7 & 2.7 & 2.3 & 2.6 & $3.1^{*}$ & $3.1^{*}$ & $3.5^{*}$ & $3.7^{*}$ & 2.7 & 3.1 & 0.4 \\
\hline \multirow[t]{4}{*}{ Control } & Fulltime & 0.87 & $0.95^{*}$ & 0.93 & 0.87 & 0.93 & 0.88 & 0.92 & 0.89 & 0.92 & 0.90 & -0.02 \\
\hline & $\begin{array}{l}\text { Hours per } \\
\text { Week }\end{array}$ & 42.56 & 46.87 & 46.70 & 42.96 & 45.68 & 44.51 & 45.25 & 43.88 & 45.3 & 44.7 & -0.6 \\
\hline & $\begin{array}{l}\text { Nominal } \\
\text { Hourly } \\
\text { Wage }\end{array}$ & 4.69 & 5.04 & 5.29 & 5.20 & 5.37 & $5.98^{*}$ & $6.70^{*}$ & $7.40^{*}$ & 5.0 & 6.1 & $1.1^{*}$ \\
\hline & $\begin{array}{l}\text { Real hourly } \\
\text { wage }\end{array}$ & 4.61 & 4.79 & 4.53 & 4.13 & 4.21 & 4.58 & 4.90 & 5.03 & 4.7 & 4.6 & -0.1 \\
\hline \multirow[t]{4}{*}{ Forestry } & Fulltime & 0.98 & 0.97 & 1.00 & 0.98 & 0.99 & 1.00 & 0.99 & 0.99 & 0.99 & 0.99 & 0 \\
\hline & $\begin{array}{l}\text { Hours per } \\
\text { Week }\end{array}$ & 50.0 & 50.9 & 51.6 & 50.8 & 49.5 & 50.9 & 49.0 & 49.6 & 50.7 & 49.0 & -1.7 \\
\hline & $\begin{array}{l}\text { Nominal } \\
\text { Hourly } \\
\text { Wage }\end{array}$ & 2.9 & 2.9 & 2.8 & 3.4 & 3.3 & $5.0^{*}$ & $4.8^{*}$ & $4.7^{*}$ & 3.5 & 4.5 & $1.0^{*}$ \\
\hline & $\begin{array}{l}\text { Real hourly } \\
\text { wage }\end{array}$ & 2.8 & 2.8 & 2.4 & 2.7 & 2.6 & 3.8 & 3.6 & 3.2 & 2.9 & 3.1 & 0.2 \\
\hline \multirow[t]{4}{*}{ Control } & Fulltime & 0.91 & $0.95^{*}$ & 0.94 & 0.89 & 0.91 & 0.88 & 0.89 & 0.91 & 0.90 & 0.91 & 0.01 \\
\hline & $\begin{array}{l}\text { Hours per } \\
\text { Week }\end{array}$ & 45.5 & 47.3 & 47.0 & 44.0 & 44.6 & 44.5 & 43.7 & 43.7 & 44.9 & 43.9 & $-1.0^{*}$ \\
\hline & $\begin{array}{l}\text { Nominal } \\
\text { Hourly } \\
\text { Wage }\end{array}$ & 5.5 & 5.6 & 5.9 & 5.5 & 5.8 & 6.3 & $7.5^{*}$ & $7.9^{*}$ & 6.0 & 7.9 & $1.9^{*}$ \\
\hline & $\begin{array}{l}\text { Real hourly } \\
\text { wage }\end{array}$ & 5.5 & 5.3 & 5.1 & 4.4 & 4.6 & 4.9 & 5.5 & 5.4 & 4.9 & 5.5 & $0.6^{*}$ \\
\hline \multirow[t]{2}{*}{ Security } & Fulltime & 0.96 & 0.98 & $0.99^{*}$ & $1.00^{*}$ & 0.99 & 0.98 & $0.99^{*}$ & 0.99 & 0.98 & 0.99 & 0.01 \\
\hline & $\begin{array}{l}\text { Hours per } \\
\text { Week }\end{array}$ & 60.2 & 58.5 & 59.4 & 55.3 & 55.0 & 57.6 & 57.3 & 57.5 & 59.0 & 57.0 & $-2.0^{*}$ \\
\hline
\end{tabular}


Table 3 Mean characteristics of employed sample (2000 to 2007), treatment and control groups (Continued)

\begin{tabular}{|c|c|c|c|c|c|c|c|c|c|c|c|c|}
\hline & $\begin{array}{l}\text { Nominal } \\
\text { Hourly } \\
\text { Wage }\end{array}$ & 6.4 & 6.8 & 7.0 & $7.9^{*}$ & $7.9^{*}$ & $8.2^{*}$ & $8.7^{*}$ & $9.4^{*}$ & 6.7 & 8.3 & $1.6^{*}$ \\
\hline & $\begin{array}{l}\text { Real hourly } \\
\text { wage }\end{array}$ & 6.3 & 6.4 & 6.0 & 6.3 & 6.2 & 6.3 & 6.3 & 6.4 & 6.4 & 6.3 & -0.1 \\
\hline \multirow[t]{4}{*}{ Control } & Fulltime & 0.96 & 0.98 & 0.98 & 0.99 & 0.98 & 0.98 & 1.00 & 0.99 & 0.97 & 0.99 & 0.02 \\
\hline & $\begin{array}{l}\text { Hours per } \\
\text { Week }\end{array}$ & 48.5 & 48.2 & 47.2 & 46.9 & 46.7 & 47.8 & 46.5 & 49.2 & 48.3 & 47.4 & -0.9 \\
\hline & $\begin{array}{l}\text { Nominal } \\
\text { Hourly } \\
\text { Wage }\end{array}$ & 9.3 & 8.3 & 11.5 & 9.8 & 10.9 & 11.5 & $12.2^{*}$ & $12.0^{*}$ & 8.6 & 11.3 & $2.7^{*}$ \\
\hline & $\begin{array}{l}\text { Real hourly } \\
\text { wage }\end{array}$ & 9.1 & 7.9 & 9.9 & 7.8 & 8.5 & 8.8 & 8.9 & 8.2 & 8.3 & 8.7 & 0.4 \\
\hline \multirow[t]{4}{*}{ Taxi } & Fulltime & 0.96 & 0.97 & 0.97 & $0.99^{*}$ & 0.95 & 0.98 & 0.96 & $1.00^{*}$ & 0.97 & 0.98 & 0.01 \\
\hline & $\begin{array}{l}\text { Hours per } \\
\text { Week }\end{array}$ & 68.4 & 67.4 & 66.3 & 67.0 & 63.1 & 68.6 & 66.9 & 67.4 & 66.6 & 67.0 & 0.4 \\
\hline & $\begin{array}{l}\text { Nominal } \\
\text { Hourly } \\
\text { Wage }\end{array}$ & 4.8 & 4.4 & 4.4 & 4.7 & 5.5 & 4.7 & 5.3 & 5.0 & 4.7 & 5.1 & 0.4 \\
\hline & $\begin{array}{l}\text { Real hourly } \\
\text { wage }\end{array}$ & 4.7 & 4.2 & 3.8 & $3.7^{*}$ & 4.3 & $3.6^{*}$ & 3.9 & $3.5^{*}$ & 4.0 & 3.7 & -0.3 \\
\hline \multirow[t]{4}{*}{ Control } & Fulltime & 0.96 & 0.98 & 0.98 & $0.99^{*}$ & 0.98 & 0.98 & 1.00 & $0.99^{*}$ & 0.98 & 0.99 & 0.01 \\
\hline & $\begin{array}{l}\text { Hours per } \\
\text { Week }\end{array}$ & 48.5 & 48.2 & 47.2 & 46.9 & 46.7 & 47.8 & 46.5 & 49.2 & 47.3 & 48.1 & 0.8 \\
\hline & $\begin{array}{l}\text { Nominal } \\
\text { Hourly } \\
\text { Wage }\end{array}$ & 9.3 & 8.3 & 11.5 & 9.8 & 10.9 & 11.5 & $12.2^{*}$ & $12.0^{*}$ & 10.2 & 12.0 & $1.8^{*}$ \\
\hline & $\begin{array}{l}\text { Real hourly } \\
\text { wage }\end{array}$ & 9.1 & 7.9 & 9.9 & 7.8 & 8.5 & 8.8 & 8.9 & 8.2 & 8.6 & 8.6 & 0 \\
\hline
\end{tabular}

Source: Data are from South African Labour Force Surveys (LFS) conducted by Statistics South Africa (September 2000 to 2007). Both September and March waves of the survey are represented in the table.

Notes: The last column shows the difference in means between the pre and the post-law periods respectively. An asterisk indicates a significant difference with base year (2000) at 5 percent or a significant difference in means between the pre-law and post-law period respectively. All statistics are self-reported by workers and statistics are weighted.

Sample includes non self-employed workers aged between 15 and 65 years inclusive. The wage variables are means for full-time workers. A fulltime worker is someone who reported at least 27 hours of work per week. The sample of covered workers includes non-government employment only. The red line indicates the timing of the introduction of the law in the respective sector.

the post-law period. All sectors and control groups experienced a significant increase in nominal hourly wages in the 2000-2007 period, with the exception of the Taxi sector. The changes in real wages were mainly not statistically significant. It may be argued that the nominal wage results may be confounded by inflation. Hence, the remainder of the discussion focuses on real wage impacts only ${ }^{25}$. In examining the number of usual weekly hours worked however, we find a significant decline in weekly hours for the Retail, Domestic, and Security sectors. The control groups do not indicate any significant changes over the period in the number of hours worked, with the exception of the control group for the Forestry sector (unskilled workers), which yields a slight decline in usual weekly hours.

In order to examine the distribution of wages at or around the minimum and the changes in the distribution of wages across time, Figure 2 presents non-parametric kernel density plots of real hourly wages (logged) for the five sectors and their respective control groups. The vertical line indicates the natural logarithm of the real hourly 
minimum (2000 prices) in the first year of introduction. A spike in the wage distribution at the minimum wage indicates that the law is binding. The kernel density plots do not reveal significant spikes at or around the minima for the five sectors examined, with a significant proportion of workers earning below the stipulated minimum. This result seems surprising, given that the presence of a spike is a common result in much of the literature, notably the US as well as some Latin American countries (DiNardo, Fortin and Lemieux, 1996; Maloney and Nuñez, 2004). This finding is analytically interesting and suggests that there may be significant noncompliance with minimum wages in these sectors ${ }^{26}$. Indeed, evidence from South Africa suggests that there may be violation of minimum wage laws. The issues of noncompliance with minimum wage laws in South Africa and the measurement and determinants of noncompliance are discussed in more detail in Bhorat, Kanbur and Mayet (2012a, b, and c). Using both an absolute and relative measure of noncompliance, they estimate that nearly 45 percent of employees affected by minimum wages in South Africa earned wages below their legislated minim in 2007, with the average shortfall of wages from the relevant minimum of those who were underpaid estimated at 35 percent.

Table 4 presents estimates of the share of workers in each of the examined sectors who received wages below the minimum following the implementation of the law.

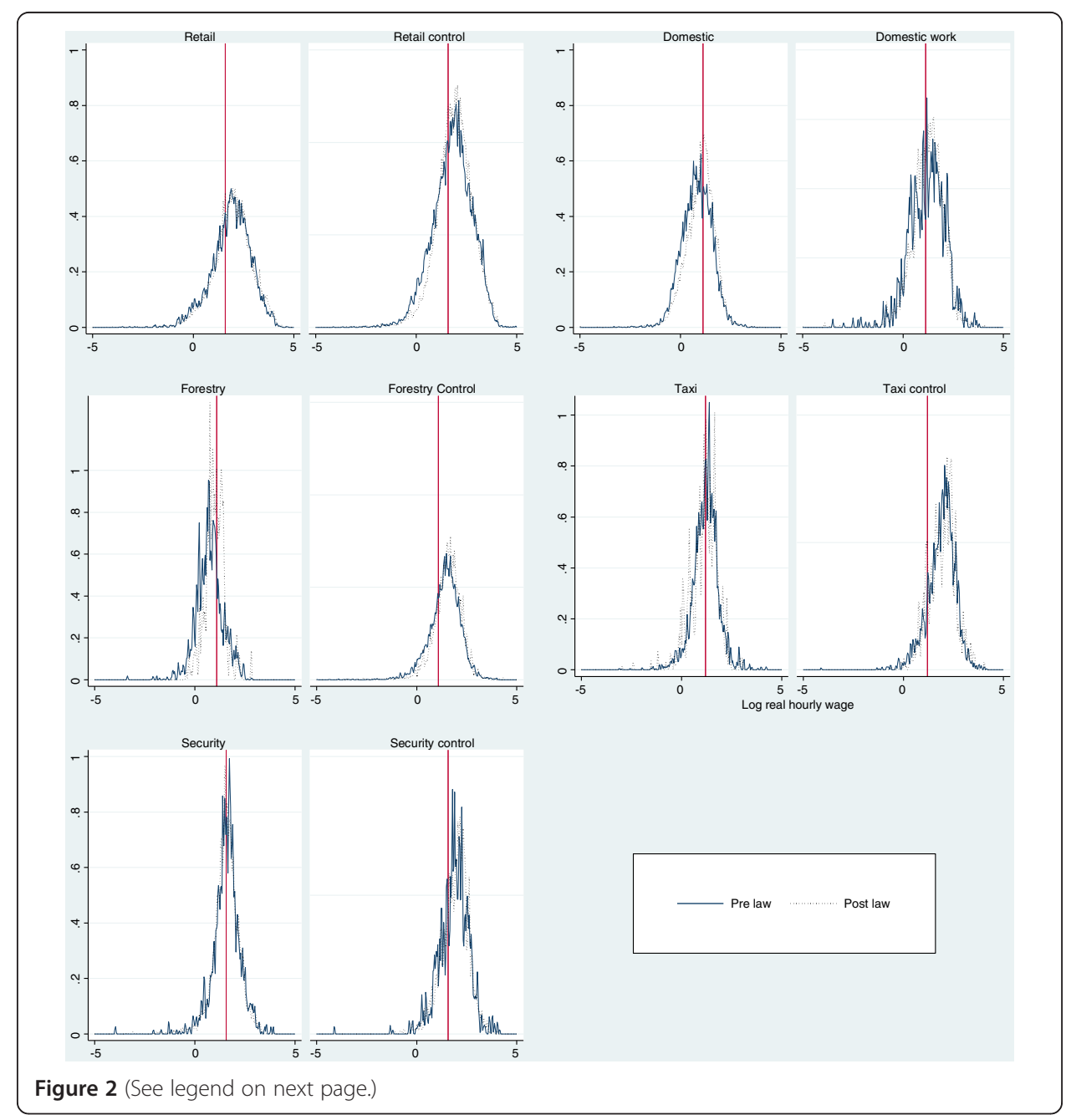


(See figure on previous page.)

Figure 2 Kernel density estimation of log of real hourly wages (2000 prices), treatment and control groups. Source: Data are from South African Labour Force Surveys (LFS) conducted by Statistics South Africa (September 2000 to September 2007. Notes: The bandwidth used in the Kernel density plots in Stata was reduced from the default bandwidth to 0.02 . The vertical line represents log of the first real hourly minimum introduced in the sector (2000 prices). Wages shown are for fulltime workers, that is, those individuals who work at least 27 hours per week. Estimates used are self-reported by workers and are for the weighted sample. Sample includes non self-employed workers aged between 15 and 65 years inclusive. The sample includes non-government employment only. The vertical line indicates the timing of the law in the respective sector. Using the Kolmogorov-Smirnov test, the null hypothesis of the equality of distributions at the 1,5 or 10 percent level is rejected for each pair-wise comparison of the before and after periods, with the exception of within the Taxi sector. For the control groups, we reject the null hypothesis of the equality of distributions for all groups, with the exception of the control group for the Security sector.

From these estimates, it is clear that there is a problem of noncompliance within the sectors examined, with the share of workers estimated to be earning below the minimum reaching $82 \%$ in the Domestic worker sector in the first year of introduction on the minimum wage. In order to examine wages near the minimum, estimates of the share of workers whose wages were below but within 10 percent of the real hourly minimum wage are also included ${ }^{27}$. The estimates suggest that the fraction of workers in the nearly compliant region of the wage distribution may have increased for certain sectors since the introduction of the minimum (notably Retail and Domestic work). The results suggest that a fraction of employers may be partially complying with minimum wage laws and paying wages a certain fraction below the minimum. However, it is crucial to note that the share of workers with wages in the 'near compliant' region of the minimum wage are far outweighed by those receiving wages that are non-compliant outside of this region. What

Table 4 Fraction of workers below the minimum by sector and year (post-law period)

\begin{tabular}{|c|c|c|c|c|c|}
\hline Fraction $<$ minimum & Retail & Domestic work & Forestry & Taxi & Security \\
\hline 2002 & & 0.82 & & & 0.53 \\
\hline 2003 & 0.50 & $0.75^{*}$ & & & 0.49 \\
\hline 2004 & 0.50 & $0.72^{*}$ & & & 0.49 \\
\hline 2005 & 0.50 & $0.74^{*}$ & & 0.56 & 0.48 \\
\hline 2006 & $0.38^{*}$ & $0.75^{*}$ & 0.56 & 0.48 & 0.49 \\
\hline 2007 & $0.40^{*}$ & $0.71^{*}$ & 0.60 & 0.64 & 0.51 \\
\hline Fraction $10 \%$ below minimum & Retail & Domestic work & Forestry & Taxi & Security \\
\hline 2002 & & 0.06 & & & 0.10 \\
\hline 2003 & 0.03 & 0.06 & & & 0.07 \\
\hline 2004 & 0.04 & 0.08 & & & 0.06 \\
\hline 2005 & 0.05 & $0.09^{*}$ & & 0.06 & 0.08 \\
\hline 2006 & 0.05 & $0.09^{*}$ & 0.06 & 0.12 & 0.08 \\
\hline 2007 & $0.07^{*}$ & 0.08 & 0.13 & 0.08 & 0.11 \\
\hline
\end{tabular}

Source: Data are from South African Labour Force Surveys (LFS) conducted by Statistics South Africa (September 2000 to 2007). Both September and March waves of the survey are represented in the table.

Notes: The minimum wage is the real hourly minimum (2000 prices). Wages used in the calculations are real hourly wages of fulltime workers. An asterisk indicates a significant difference with the first year of introduction of the minimum wage in the respective sector at 5 percent. All statistics are self-reported by workers and estimated are weighted. Sample includes non self-employed workers aged between 15 and 65 years inclusive. Only estimates for fulltime workers are shown. A fulltime worker is someone who reported at least 27 hours of work per week. The sample of minimum wage affected workers includes non-government employment only. 
then, the lack of a spike in the wage distributions is strongly suggestive of is low levels of compliance with the law across all minimum wage schedules.

As the results above suggest, although compliance with minimum wage laws may be imperfect, shifts in the wage distribution may still occur as employers may be partially complying with the minimum wage laws. In this paper, we therefore examine shifts in the overall distribution in order to determine whether the laws had an impact on the respective sectors. Examining the shifts in the distribution between the pre-law and the post-law periods then, the results suggest that there is some evidence of a rightward shift in the post-law wage distributions for most of the sectors examined. Kolmogorov-Smirnov tests performed to test for distributional differences between the pre-law and the post-law periods indicate that the post-law distribution is significantly different from that of the pre-law period for the Retail, Domestic, Forestry, and Security sectors. An exception is the Taxi sector, for which the Null hypothesis of the equality of distributions is not rejected at the 10 percent level.

Finally, Figure 3 examines the distribution of hours worked per week in the pre- and post-law periods. The plots indicate that the distribution shifted leftwards for most of the sectors in the period after the introduction of the law. We reject the Null hypothesis for the equality of distributions using the Kolmogorov-Smirnov test for the Retail, Domestic, Forestry and Security sectors at the 10 percent level. This suggests a significant downward shift in hours worked in four out of the five sectors examined in the post-law period.

Overall then, the descriptive results suggest that whilst a significant decline in employment is not observed for most sectors in the post-law period, there is some indication that minimum wage sectors experienced an increase in wages and a reduction in hours worked after the law was introduced. We now turn to an econometric analysis of the impact of the sectoral minimum wage laws below.

\section{Econometric results}

As outlined above, two alternative specifications of a difference-in-differences model are used in order to investigate the effects of the introduction of minimum wage laws on the applicable sectors. The effects of the legislated minima are investigated on employment, wage levels and hours of work. An analysis of the results may be used to indicate whether the changes observed within a sector were unique to the specific group of workers, as well as whether the impact of the law was larger in district councils where pre-law wages were lower relative to the introduced minima. The results from the difference-in-differences analysis are presented in Tables 4 through 6.

Table 5 shows the results from the difference-in-differences estimation of the impact of the sectoral minima on the probability of employment. For each of the five sectors examined, the first specification shown estimates the employment equation with individual level controls, specifically age, education, gender and race. The second specification includes both individual level controls as well as controls for district councils. The dependent variable is a binary variable equal to 1 if the individual is employed in the respective sector covered by the minimum wage law, and equal to 0 otherwise ${ }^{28}$. As stated earlier, the sample in the equations for employment includes all employed individuals and demographically similar unemployed working age individuals who are searching for work. Therefore the sample in each wave in the employment equations for each 


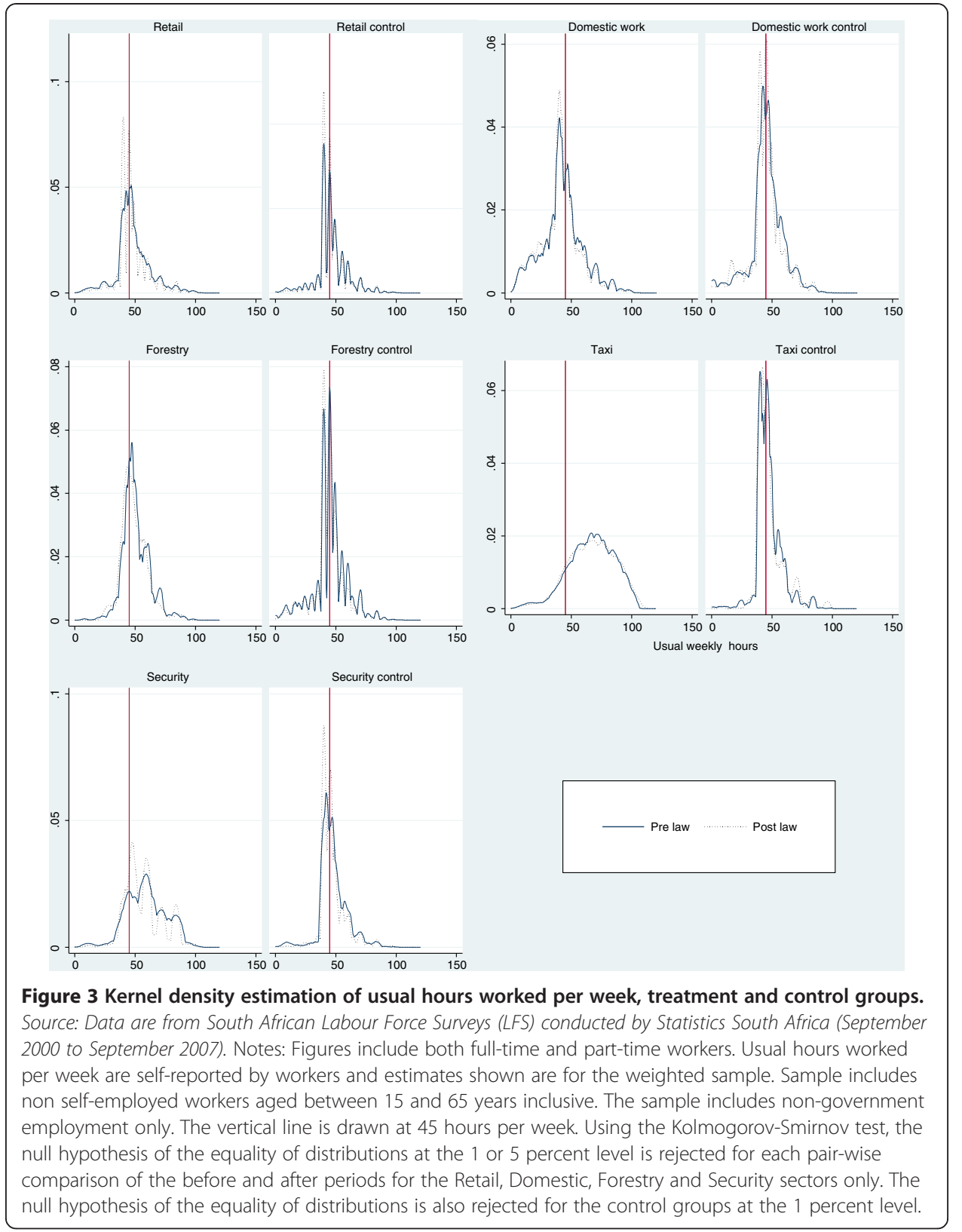

sector includes individuals who are employed in the respective minimum wage sector, individuals who are employed in other sectors (this includes other minimum wage affected sectors ${ }^{29}$ ), and those individuals who are unemployed but searching for work (narrow unemployed).

Contrary to the results predicted under a standard competitive model however, the results presented here for the employment equations do not yield a significant negative effect of the minimum wage on employment for the sectors analysed. The coefficient on the Post $_{t}$ variable for the Retail, Domestic, and Security sectors is positive and significant, suggesting that the probability of employment in these sectors was higher in the post-law period. The results show no significant change in the probability of employment for the Forestry sector in the period after the introduction of the law in 2006. 
Table 5 Probability of employment by sector (Dependent variable $=$ Pr (Employment))

\begin{tabular}{|c|c|c|c|c|c|c|c|c|c|c|}
\hline \multirow[t]{2}{*}{ Sector } & \multicolumn{2}{|c|}{ Retail } & \multicolumn{2}{|c|}{ Domestic } & \multicolumn{2}{|c|}{ Forestry } & \multicolumn{2}{|c|}{ Taxi } & \multicolumn{2}{|c|}{ Security } \\
\hline & 1 & II & I & II & $\mathrm{I}$ & II & I & II & I & II \\
\hline \multirow[t]{2}{*}{ Post } & $0.0038^{* *}$ & $0.0038^{* *}$ & $0.0066^{* * *}$ & $0.0061^{* * *}$ & -0.0005 & 0.0003 & $-0.0030^{* * *}$ & $-0.0030^{* * *}$ & $0.0039^{* * *}$ & $0.0026^{* *}$ \\
\hline & $(0.0017)$ & $(0.0018)$ & $(0.0022)$ & $(0.0022)$ & $(0.0009)$ & $(0.0007)$ & $(0.0004)$ & $(0.0004)$ & $(0.0012)$ & $(0.0011)$ \\
\hline \multirow[t]{2}{*}{ Wage gap } & -0.0001 & & $-0.0126^{* * *}$ & & $0.0058^{* *}$ & & -0.00001 & & $-0.0034^{*}$ & \\
\hline & $(0.0018)$ & & $(0.0045)$ & & $(0.0026)$ & & $(0.0001)$ & & $(0.0017)$ & \\
\hline \multirow[t]{2}{*}{ Wage gap*Post } & -0.0002 & -0.0003 & -0.0005 & -0.0004 & -0.0001 & -0.0004 & 0.00005 & 0.00004 & 0.0001 & 0.0002 \\
\hline & $(0.0015)$ & $(0.0015)$ & $(0.0017)$ & $(0.0017)$ & (0.0008) & $(0.0007)$ & $(0.0001)$ & $(0.00005)$ & (0.0009) & (0.0009) \\
\hline Individual controls included & Yes & Yes & Yes & Yes & Yes & Yes & Yes & Yes & Yes & Yes \\
\hline District controls included & No & Yes & No & Yes & No & Yes & No & Yes & No & Yes \\
\hline \multirow[t]{2}{*}{ Constant } & $0.0231^{* * *}$ & $0.0327^{* * *}$ & $0.0192^{* *}$ & -0.0003 & 0.0006 & $0.0222^{* * *}$ & $0.0059^{* * *}$ & $0.0033^{* * *}$ & $0.0293^{* * *}$ & -0.0047 \\
\hline & $(0.0064)$ & $(0.0062)$ & $(0.0086)$ & $(0.0066)$ & $(0.0011)$ & $(0.0057)$ & $(0.0007)$ & $(0.0009)$ & $(0.0032)$ & (0.0036) \\
\hline Observations & 493,809 & 493,809 & 493,809 & 493,809 & 267,108 & 267,108 & 455,266 & 455,266 & 464,046 & 464,046 \\
\hline Number of districts & 52 & 52 & 52 & 52 & 30 & 30 & 45 & 45 & 46 & 46 \\
\hline R-squared & 0.0130 & 0.0150 & 0.0970 & 0.1040 & 0.0040 & 0.0180 & 0.0040 & 0.0050 & 0.0100 & 0.0160 \\
\hline F-statistic & $193.75^{* * *}$ & $162.68^{* * *}$ & $124^{* * *}$ & $167.85^{* * *}$ & $2.51^{* *}$ & $2.41^{*}$ & $26.36^{* * *}$ & $51.9^{* * *}$ & $43.76^{* * *}$ & $52.59^{* * * *}$ \\
\hline
\end{tabular}

Source: Data are from South African Labour Force Surveys (LFS) conducted by Statistics South Africa (15 waves September 2000 to September 2007).

Notes: Dependent variable is a dummy variable equal to 1 if the individual is employed in the respective sector and equal to 0 otherwise. The sample includes individuals of working age who are employed or seeking work, and who have completed no more than 12 years of schooling (Matric). Robust standard errors clustered by district council are shown in parentheses. ${ }^{* * *} p<0.01,{ }^{* * *} p<0.05$, ${ }^{*} p<0.1$. Individual controls include controls for race, years of schooling and gender. The wage gap measures the proportional increase in the real wages of workers in district council $i$ at time $t-1$ necessary to meet the minimum wage at time $t$. The F-statistic refers to the test for the null hypothesis that the regression coefficients are equal to zero, which is rejected at the 1, 5 and 10 percent levels. 
Only the Taxi sector yields a negative and significant coefficient for the Post $t_{t}$ variable, suggesting that the probability of employment in that sector dropped slightly in the period following the introduction of the law.

The coefficients for the Gap ${ }_{j k}$ variable in Specification (1) were negative and significant at the 1 and 10 percent level for the Domestic worker and Security sectors respectively. The negative results are suggestive of a reduced probability of employment in those sectors in district councils where the pre-law wages were farther below the introduced minima. For the Forestry sector, this result is positive, indicating a higher probability of employment in the Forestry sector in district councils where wages were the lowest relative to the minima. This result may be explained by the low wages in the Forestry sector relative to other sectors, and may simply be capturing districts with more Forestry workers and therefore lower wages. The Retail and the Taxi sectors yield an insignificant result for the pre-law wage gap variable. The interaction effect between the Gap jk $_{k}$ variable and the Post $_{t}$ variable included in both specifications measures the effect of the law in the post-law period in district councils where the minimum wage was most binding. However, this variable does not yield a significant result in any of the equations. Overall, we conclude then that the evidence here does not indicate a significant effect of the introduction of minimum wages in the respective sectors at the extensive margin.

The second outcome examined here is wage levels. The descriptive evidence presented above indicates that all minimum wage sectors experienced a significant increase in nominal wages in the post-law period. Whilst real wages also increased in some of the sectors, the increase in real wages is less evident than the increase in nominal wages. Furthermore, the observed increase in wages in the respective minimum wage sectors may have been due to factors external to the introduction of the sectoral laws. A difference-in-differences approach as outlined above is therefore used to firstly, test whether or not the introduced minima had an effect on the wages of covered workers relative to a similar group of workers who were not affected by the law, and secondly, to measure the differential effect of the introduced minima in areas where the pre-law wages of the respective sector were further below the minima. The effects of the minima on real wages are investigated, and the results are shown in Table $6^{30}$. The dependent variable was the log of real wages in 2000 prices. All specifications include controls for individual characteristics, that is, age, gender, education and race. For each of the sectors, the sample in the first specification includes workers employed in the relevant sector who are covered by the minimum wage, and workers in a control group. The results from this specification compare the wages of workers in the specific sector against wages of individuals in the control group. The second and third specifications include only workers in the relevant minimum wage sector, and measure whether wages increased more in areas where the pre-law wage gap was the largest. Whilst Specification (II) does not include controls for district councils, Specification (III) provides a test of robustness of the results in Specification (II) by including district council level controls. Specification (III) is therefore considered as the preferred estimation in the analysis. As mentioned above, whilst the district-council specific Gapjk measure is dropped in the third specification, the key difference-in-difference indicator, notably

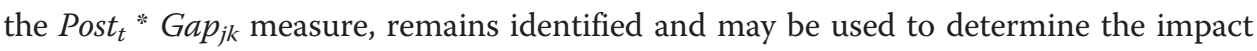
of the law on the outcome variable. 
Table 6 Log of real hourly wages, difference-in-differences (Dependent variable $=$ log real hourly wage in 2000 prices)

\begin{tabular}{|c|c|c|c|c|c|c|c|c|c|c|c|c|c|c|c|}
\hline & \multicolumn{3}{|c|}{ Retail } & \multicolumn{3}{|c|}{ Domestics } & \multicolumn{3}{|c|}{ Forestry } & \multicolumn{3}{|c|}{ Taxi } & \multicolumn{3}{|c|}{ Security } \\
\hline & 1 & II & III & $I$ & II & III & $I$ & II & III & 1 & II & III & 1 & II & III \\
\hline \multirow[t]{2}{*}{ Post } & $0.0517^{* *}$ & -0.0041 & -0.0066 & 0.0641 & $0.0727^{* * *}$ & $0.0547^{* *}$ & $0.128^{* * *}$ & $0.195^{* *}$ & $0.195^{* *}$ & 0.0289 & -0.0662 & -0.0021 & 0.0403 & -0.0690 & -0.0671 \\
\hline & (0.0198) & (0.0194) & $(0.0192)$ & $(0.0431)$ & $(0.0230)$ & $(0.0239)$ & $(0.0189)$ & $(0.0905)$ & $(0.0869)$ & $(0.0314)$ & $(0.0562)$ & (0.0398) & $(0.0344)$ & $(0.0479)$ & $(0.0435)$ \\
\hline \multirow[t]{2}{*}{ Sector } & $-0.0622^{* * *}$ & & & $-0.394^{* * *}$ & & & $-0.209^{* * *}$ & & & $-0.646^{* * *}$ & & & $-0.380^{* * *}$ & & \\
\hline & $(0.0217)$ & & & $(0.0451)$ & & & $(0.0773)$ & & & $(0.0413)$ & & & $(0.0386)$ & & \\
\hline \multirow[t]{2}{*}{ Sector*Post } & -0.0122 & & & 0.0554 & & & 0.0325 & & & -0.00936 & & & -0.0246 & & \\
\hline & $(0.0234)$ & & & $(0.0437)$ & & & $(0.0740)$ & & & $(0.0512)$ & & & $(0.0524)$ & & \\
\hline \multirow[t]{2}{*}{ Wage gap } & & $-0.286^{* * *}$ & & & $-0.536^{* * *}$ & & & 0.0055 & & & $-0.0250^{* * *}$ & & & $-0.387^{* * *}$ & \\
\hline & & $(0.0563)$ & & & $(0.0341)$ & & & $(0.0567)$ & & & (0.0088) & & & $(0.108)$ & \\
\hline \multirow[t]{2}{*}{ Wage gap*Post } & & $0.0651^{* * *}$ & $0.0568^{* *}$ & & $0.0552^{* *}$ & $0.0698^{* * *}$ & & -0.0113 & -0.0079 & & $0.0190^{* * *}$ & $0.0152^{* * *}$ & & $0.232^{* * *}$ & $0.272^{* * *}$ \\
\hline & & $(0.0216)$ & $(0.0213)$ & & $(0.0249)$ & $(0.0254)$ & & (0.0378) & $(0.0334)$ & & $(0.0045)$ & $(0.0033)$ & & $(0.0802)$ & $(0.0635)$ \\
\hline Individual Controls & Yes & Yes & Yes & Yes & Yes & Yes & Yes & Yes & Yes & Yes & Yes & Yes & Yes & Yes & Yes \\
\hline District controls & Yes & No & Yes & Yes & No & Yes & Yes & No & Yes & Yes & No & Yes & Yes & No & Yes \\
\hline \multirow[t]{2}{*}{ Constant } & $0.978^{* * *}$ & $0.687^{* * *}$ & $0.636^{* * *}$ & $0.630^{* * *}$ & $0.810^{* * *}$ & $0.234^{* * *}$ & $0.778^{* * *}$ & $0.622^{* * *}$ & $0.411^{* *}$ & $1.317^{* * *}$ & $1.083^{* * *}$ & $0.995^{* * *}$ & $1.380^{* * *}$ & $1.198^{* * *}$ & $1.137^{* * *}$ \\
\hline & $(0.0495)$ & $(0.0865)$ & $(0.0521)$ & $(0.0830)$ & $(0.0895)$ & $(0.0693)$ & $(0.0593)$ & $(0.163)$ & $(0.162)$ & $(0.0661)$ & $(0.170)$ & $(0.107)$ & $(0.0716)$ & $(0.125)$ & $(0.0950)$ \\
\hline Observations & 64,974 & 18,986 & 18,986 & 30,601 & 25,874 & 25,874 & 15,202 & 1,840 & 1,840 & 4,630 & 1,659 & 1,659 & 9,451 & 6,281 & 6,281 \\
\hline Number of districts & 53 & 52 & 52 & 53 & 52 & 52 & 53 & 29 & 29 & 53 & 45 & 45 & 53 & 46 & 46 \\
\hline R-squared & 0.383 & 0.368 & 0.419 & 0.333 & 0.274 & 0.318 & 0.309 & 0.103 & 0.231 & 0.393 & 0.040 & 0.20 & 0.251 & 0.138 & 0.204 \\
\hline F-statistic & $476.49^{* * *}$ & $187.06^{* * *}$ & $302.46^{* * *}$ & $64.62^{* * *}$ & $208.25^{* * *}$ & $44.39^{* * *}$ & $90.37^{* * *}$ & $63.02^{* * *}$ & $154.70^{* * *}$ & $136.74^{* * *}$ & $7.45^{* * *}$ & $9.54^{* * *}$ & $179.39^{* * *}$ & $37.26^{* * *}$ & $85.91^{* * *}$ \\
\hline
\end{tabular}

Source: Data are from South African Labour Force Surveys (LFS) conducted by Statistics South Africa (15 waves September 2000 to September 2007).

Notes: The dependent variable is the log of the real hourly wage for full-time workers (those individuals who report working a minimum of 27 hours per week). Sample includes non self-employed workers aged

between 15 and 65 years inclusive. The sample includes non-government employment only. In the first specification the sample includes the treatment and the control group only, whilst in the second specification,

the sample is restricted to the sector of interest only. Robust standard errors clustered by district council are shown in parentheses. ${ }^{* * *} p<0.01,{ }^{* * *} p<0.05,{ }^{*} p<0.1$. Individual controls include controls for race, years of schooling and gender. The wage gap measures the proportional increase in the real wages of workers in district council $i$ at time $t-1$ necessary to meet the minimum wage at time $t$. The F-statistic refers to the test for the null hypothesis that the regression coefficients are equal to zero, which is rejected at the 1 percent level. 
Considering the results for real wages (Table 6), our difference-in-differences estimates from Specification (I) suggest that in two of the five minimum wage schedules examined, namely Retail and Forestry, average real wages in the post-law period rose significantly relative to the relevant control group (approximately between 5 and 13 percent in Retail and Forestry respectively). For the remaining three sectors, no significant change occurred. The coefficients on the sector dummy variables for all five sectors are negative and statistically significant, indicating that individuals in these sectors earned significantly lower wages in real terms than their control groups in the overall period. This result is as expected, given that minimum wage laws were introduced in sectors where wages were generally considered to be low. The difference-in-difference estimator, notably the Post $_{t}$ * Sector $k$ variable, yields an insignificant coefficient for all five sectors. The results from Specification (I) therefore do not suggest a positive impact of the law on real wages of workers in the five sectors examined in the post-law period relative to their control groups.

However, as noted above, spillover effects may exist when using control group comparisons. Therefore, Specifications (II) and (III) are estimated on only those individuals employed in the respective sector and may be considered as the preferred set of results. Specification (II) tests whether wages increased more in district councils where the pre-law wage gap was larger ${ }^{31}$. The significant and positive coefficient on the Post $_{t}$ variable indicates that in the post-law period real wages rose on average in two of the five sectors, namely Domestic work, and Forestry. The negative and significant result on the pre-law wage gap variable for the Retail, Domestic, Taxi and Security sectors indicates that in district councils where the pre-law wage gap was larger, hourly wages were lower. This result is as expected, given that district councils with larger wage gaps are reflective of a larger number of workers with lower wages. The difference-in-difference estimator, the Post $_{t}$ * Gap $j$ variable, yields a significant and positive coefficient in all sectors examined, barring the Forestry sector. This result suggests that workers in these sectors who were located in district councils where the wage gap was larger experienced a larger increase in their earnings during the post-law period compared to their counterparts located in district councils with a lower pre-law wage gap. Specification (III) tests the robustness of these results to the inclusion of district council level controls. The positive and significant coefficient for the Post $_{t}$ * Gap $j k$ variable for the Retail, Domestic, Taxi and Security worker sectors suggests that district councils with larger wage gaps were associated with larger increases in real earnings during the post-law period. Collectively then, the results here suggest that the introduction of minimum wage laws were associated with positive increases in real hourly earnings in the postlaw period in four of the five sectors examined.

The impact of minimum wage laws on the number of usual hours worked per week is now considered. Employers may reduce the number of hours worked in order to pay the higher wages specified by the minimum wage schedules, or to comply with the maximum number of weekly hours set out by the respective sectoral law. Hamermesh (1993) argues that employers may be quicker to adjust the number of hours worked by employees than to adjust employment. Table 7 presents the results from the differencein-differences analysis on the changes in the number of usual hours worked per week, for each of the five sectors between 2000 and 2007. The significant and positive results for the sectoral dummies in the first specification for Retail, Taxi and Security workers 
Table 7 Usual hours worked per week, difference-in-differences (Dependent variable: Number of usual weekly hours)

\begin{tabular}{|c|c|c|c|c|c|c|c|c|c|c|c|c|c|c|c|}
\hline & \multicolumn{3}{|c|}{ Retail } & \multicolumn{3}{|c|}{ Domestics } & \multicolumn{3}{|c|}{ Forestry } & \multicolumn{3}{|c|}{ Taxi } & \multicolumn{3}{|c|}{ Security } \\
\hline & 1 & II & III & 1 & II & III & 1 & II & III & 1 & II & III & 1 & II & III \\
\hline \multirow[t]{2}{*}{ Post } & $-0.315^{* *}$ & $-1.444^{* * *}$ & $-1.346^{* * *}$ & -1.016 & -1.255 & -1.063 & $-1.382^{* * *}$ & -1.285 & -1.048 & 0.474 & 0.619 & 0.656 & $-1.347^{* * *}$ & $-2.174^{* * *}$ & $-2.339^{* * *}$ \\
\hline & $(0.137)$ & $(0.357)$ & $(0.357)$ & $(0.607)$ & $(0.861)$ & $(0.826)$ & (0.299) & $(1.360)$ & $(1.497)$ & $(0.849)$ & (2.585) & (2.848) & $(0.476)$ & $(0.677)$ & $(0.635)$ \\
\hline \multirow[t]{2}{*}{ Sector } & $3.163^{* * *}$ & & & -1.272 & & & 0.516 & & & $20.17^{* * *}$ & & & $11.75^{* * *}$ & & \\
\hline & $(0.304)$ & & & $(0.840)$ & & & $(0.701)$ & & & $(0.729)$ & & & $(0.753)$ & & \\
\hline \multirow[t]{2}{*}{ Sector*Post } & $-1.203^{* * *}$ & & & -0.352 & & & 0.0757 & & & -0.789 & & & $-1.741^{* *}$ & & \\
\hline & $(0.232)$ & & & $(0.724)$ & & & $(1.080)$ & & & $(2.416)$ & & & $(0.755)$ & & \\
\hline \multirow[t]{2}{*}{ Wage gap } & & $2.719^{* * *}$ & & & $3.186^{* *}$ & & & $-0.394^{* *}$ & & & $0.331^{* * *}$ & & & $3.622^{*}$ & \\
\hline & & $(0.586)$ & & & (1.333) & & & $(0.166)$ & & & $(0.0729)$ & & & $(2.121)$ & \\
\hline \multirow[t]{2}{*}{ Wage gap*Post } & & -0.128 & -0.108 & & -0.0221 & -0.319 & & -1.153 & -1.251 & & $-0.772^{* * *}$ & $-0.751^{* * *}$ & & -2.561 & -2.706 \\
\hline & & $(0.350)$ & $(0.351)$ & & (0.632) & $(0.605)$ & & $(0.781)$ & $(0.845)$ & & $(0.215)$ & $(0.227)$ & & $(1.971)$ & $(1.767)$ \\
\hline Individual Controls & Yes & Yes & Yes & Yes & Yes & Yes & Yes & Yes & Yes & Yes & Yes & Yes & Yes & Yes & Yes \\
\hline District controls & Yes & No & Yes & Yes & No & Yes & Yes & No & Yes & Yes & No & Yes & Yes & No & Yes \\
\hline \multirow[t]{2}{*}{ Constant } & $49.13^{* * * *}$ & $52.63^{* * * *}$ & $54.28^{* * * *}$ & $51.01^{* * * *}$ & $44.02^{* * *}$ & $49.72^{* * *}$ & $49.67^{* * *}$ & $50.82^{* * * *}$ & $55.39^{* * * *}$ & $45.76^{* * *}$ & $58.20^{* * * *}$ & $56.58^{* * * *}$ & $49.59^{* * * *}$ & $60.95^{* * * *}$ & $61.95^{* * *}$ \\
\hline & $(0.405)$ & $(1.042)$ & $(0.719)$ & $(1.140)$ & (1.119) & $(0.962)$ & (1.238) & (1.865) & (3.434) & $(1.790)$ & (3.034) & (3.125) & $(2.056)$ & $(2.447)$ & $(2.440)$ \\
\hline Observations & 64,974 & 18,986 & 18,986 & 30,601 & 25,874 & 25,874 & 15,202 & 1,840 & 1,840 & 4,630 & 1,659 & 1,659 & 9,451 & 6,281 & 6,281 \\
\hline Number of districts & 53 & 52 & 52 & 53 & 52 & 52 & 53 & 29 & 29 & 53 & 45 & 45 & 53 & 46 & 46 \\
\hline R-squared & 0.082 & 0.089 & 0.113 & 0.093 & 0.048 & 0.106 & 0.052 & 0.015 & 0.048 & 0.387 & 0.015 & 0.076 & 0.152 & 0.023 & 0.057 \\
\hline F-statistic & $117.91^{* * *}$ & $58.48^{* * *}$ & $42.99^{* * *}$ & $23.84^{* * *}$ & $11.8^{* * *}$ & $12.92^{* * *}$ & $8.71^{* * *}$ & $5.89^{* * *}$ & $3.26^{* *}$ & $149.10^{* * *}$ & $37.35^{* * *}$ & $27.10^{* * *}$ & $130.04^{* * *}$ & $24.97^{* * *}$ & $23.40^{* * *}$ \\
\hline
\end{tabular}

Source: Data are from South African Labour Force Surveys (LFS) conducted by Statistics South Africa (15 waves September 2000 to September 2007).

Notes: The dependent variable is the usual number of hours worked per week as reported for full-time workers (those individuals who report working a minimum of 27 hours per week). Sample includes non self-

employed workers aged between 15 and 65 years inclusive. The sample includes non-government employment only. In the first specification the sample includes the treatment and the control group only, whilst in the second specification, the sample is restricted to the sector of interest only. Robust standard errors clustered by district council are shown in parentheses. ${ }^{* * *} p<0.01,{ }^{* *} p<0.05{ }^{*}, p<0.1$. Individual controls include controls for race, years of schooling and gender. The wage gap measures the proportional increase in the real wages of workers in district council $i$ at time $t-1$ necessary to meet the minimum wage at time $t$. The F-statistic

refers to the test for the null hypothesis that the regression coefficients are equal to zero, which is rejected at the 1 percent level. 
indicate that workers in these sectors worked a larger number of hours relative to those in the respective control groups in the overall period. The results for the estimated coefficients for the difference-in-difference term ( Post $_{t}$ * Sector $k$ ) suggest that in the Retail and Security sectors employers adjusted significantly at the intensive margin to accommodate the increase in the wage bill. The coefficient for the difference-indifference estimator is negative and significant for both these sectors, suggesting that there was a significant decline in the number of hours worked in the post-law period relative to the relevant control group. Specifications (II) and (III) also yield a significant decline in average weekly hours during the post-law period for the Retail and Security sectors. However, the difference-in-differences parameter on the Post $_{t}{ }^{*}$ Gap $_{j k}$ variable was not significant for these sectors, suggesting that the effect on hours worked across district councils did not vary depending on the intensity of the minimum introduced. The second and third specifications do however yield a significant and negative coefficient for the difference-in-difference estimator for the Taxi sector, suggesting a negative adjustment at the intensive margin due to the introduction of the law for this sector. Overall however, the results do indicate that whilst the estimates for employment do not yield significant adjustments, there is some evidence that employers may have adjusted at the intensive margin in certain sectors.

Collectively then, the above suggests that real hourly wages increased in most of the minimum wage covered sectors analysed, with larger increases occurring in district councils where workers were further below the introduced minimum. For some sectors, there is also evidence of a downward intensive margin adjustment in the post-law period. Due to the adjustment in both real hourly wages and hours of work for some of the sectors, it is unclear whether or not workers in those sectors were better off in real income terms following the enactment of the legislation. Therefore, we attempted to explore the implications of the above results by using real monthly earnings instead as an outcome variable in a difference-in-differences analysis ${ }^{32}$. The results showed that workers in three of the five sectors, namely Retail, Domestic Work, and Security, were better off in terms of real monthly wages following the introduction of the law. For the Retail and Security sectors, the results from the difference-in-differences analysis indicated that the rise in real hourly wages was sufficient to offset the adjustment observed at the intensive margin in these sectors. Consequently, there was a significant increase in monthly earnings following the introduction of the law. In the Domestic worker sector, whilst real monthly wages increased significantly during the post-law period, there was so significant impact of the law at the intensive margin. As a result, workers in this sector were better off in terms of real monthly wages following the introduction of the law. Meanwhile, in the Forestry and the Taxi sectors, the results suggest that real hourly wage increases were offset by intensive margin adjustments, yielding overall an insignificant effect on total monthly wages in the post-law period. The Forestry sector yielded an insignificant impact of the law on real hourly wages and hours of work, and therefore workers were no better or worse off after the legislation in real income terms. On the other hand, in the Taxi sector, the results imply that increases in real hourly wages were offset by negative adjustments at the intensive margin, yielding an overall insignificant effect of the law on real monthly wages. The interaction between an adjustment in hours of work and the real wage earned following the advent of the minimum wage is therefore crucial. These results suggest that intensive margin adjustments 
by employers can be accompanied by real wage effects which can at the aggregate level, actually make workers better off.

\section{Conclusion}

The standard competitive model predicts that firms will reduce employment in response to the minimum wage, in turn causing a negative employment effect to be observed. However, our analysis above of the effect of the introduction of a minimum wage in a low-wage sector shows no clear evidence that the introduction of minimum wage laws had a significant impact on employment in a given period for the five sectors analysed. Although the results here appear to be at odds with the standard prediction from many earlier studies that found a negative employment impact of minimum wages (Brown et al. 1982; Charles et al. 1983), they are consistent with some of the more recent international studies on minimum wages that do not always find a negative employment effect associated with the minimum wage (Katz and Krueger 1992; Card and Krueger, 1995).

We also find some evidence of a significant increase in real hourly wages in the postlaw period as a result of the introduction of a minimum wage, and that wages increased more in district councils where pre-law wages were further below the introduced minimum in four of the five sectors examined (Retail, Domestic work, Taxi and Security). The results for the Domestic worker sector are consistent with other South African studies on the impact of minimum wages in this sector, that show that whilst minimum wage laws were not found to have a significant impact on employment, they were associated with a significant increase in wages within the sector (Dinkelman and Ranchhod, 2012; Hertz, 2005).

Whilst there is no strong evidence for negative employment adjustments at the extensive margin of labour demand, the results do suggest that the sectoral minima did have some effect at the intensive margin. There is some indication that for sectors where employment continued to rise in the post-law period, notably the Retail and Security sectors, the introduction of minimum wages may have been associated with a reduction in the usual number of weekly hours worked. This result may be indicative of employers adjusting at the intensive margin in order to pay higher wages. Three of the five sectors (Retail, Domestic and Security) showed an increase in real hourly wages that was sufficient to outweigh any adjustments at the intensive margin, resulting in workers in these sectors experiencing an improvement in their real monthly income as a consequence of the enactment of the law. For the remaining two sectors (Forestry and Taxi) the evidence suggests that workers in these sectors may not have been any better or worse off in real income terms in the period following the introduction of the legislation.

Ultimately then, through the use of a fairly standard set of econometric techniques, this study has provided an exhaustive set of estimates on the employment, wage and hours of work responses to multiple sectoral minimum wage schedules in South Africa. As an African, middle-income country these estimates are unique in and of themselves. As part of the new minimum wage literature this paper has suggested that the theoretical wage-employment trade-off is not always readily observed in practice, and furthermore, that the medium-term labour market consequences of minimum wage policy are far more varied and unpredictable than most theory would suggest. 


\section{Endnotes}

${ }^{1}$ Minimum wages were first introduced under the Fair Labour Standards Act (1938).

${ }^{2}$ New Zealand was the first country to introduce minimum wage legislation in 1894 (Starr 1981); Minimum wages first came into effect in the United Sates as part of the Fair Labour Standards Act in 1938.

${ }^{3}$ Gindling and Terrell $(2005,2007)$ note that a search of articles published on minimum wages using popular search engines reveals that for the 1985-2000 period, only 22 studies were on countries other than the U.S, compared with 120 using U.S. data.

${ }^{4}$ Department of Labour (1999) Government Notice No. 622. Sectoral Determination 1: Contract Cleaning Sector, South Africa. Available from:<http://www.labour.gov.za/legislation/sectoral-determinations/sectoral-determination-1-contract-cleaning-sector $>$.

${ }^{5}$ In terms of the construction of our weights, the earlier LFS surveys up to 2002 are benchmarked to the 1996 Census, whereas the later surveys for the post-2002 period are benchmarked to the 2001 Census. Therefore, the use of the LFS weights in analysing cross-sectional data across time raises concerns around the consistency of results (Hertz, 2005; Hertz, 2006). discusses how the inconsistencies arising from the weights used can affect any analysis of the impact of minimum wage laws. We use a set of individual weights developed by Branson (2009) on the basis of entropy estimation, which we believe to be more reliable than the StatsSA weights. The weights are available from Data First at the University of Cape Town (See <http://www.datafirst.uct.ac.za $>$ ).

${ }^{6}$ Bhorat et. al. (2012b) provide a detailed description of minimum wage institutions in South Africa.

7 The minima are regularly updated for inflation and using increases of different percentages. For example, in the Retail sector, the minima are updated as follows: Current annual minimum $=$ Previous year's minimum wage + CPIX $+1 \%$.

${ }^{8}$ Of the remaining sectors affected by minimum wage laws, two are not identifiable using the Labour Force Survey data; namely Learnerships, and Children in the Performance of Advertising, Artistic and Cultural Activities. Employment information in the Labour Force Survey is only provided for individuals in the working age population, that is, individuals aged between 15 and 65 years.

${ }^{9}$ The earliest dataset available is the September 2000 Labour Force Survey, whilst the September 2007 Labour Force Survey remains the most recent dataset with useable wage data in South Africa.

${ }^{10}$ This created a problem particularly when generating the Wage Gap variable that is used in the model, which is constructed as the gap between the minimum and the mean wage in the pre-law in a district. Due to the small number of Civil Engineers we are able to identify in the dataset, there are some districts where no Civil Engineers are found and a Wage gap cannot be specified for these districts.

${ }^{11}$ These included types of machine and plant operators who were not affected by any minimum wage laws.

${ }^{12}$ Bhorat, Stanwix, and Kanbur (2011) use a similar control group in order to investigate the impact of the minimum wage on employment in a specific sector. Another application, albeit not a difference-in-difference model, is found in Gindling and Terrell (2005, 2007).

${ }^{13}$ As explained further below in the discussion of the econometric results, we explored excluding workers employed in other minimum wage affected sectors in each 
wave from the regressions. However, the results reported here are from what we consider to be the more complete specification of the control group that is, including individuals who may have switched jobs between sectors between survey waves.

14 The Labour Force Survey provides four-digit occupational codes based on the South African Classification of Occupations (SASCO) and three-digit industrial codes (International Standard Industrial Classification of all Economic Activities).

15 This mapping was previously done in Bhorat et al. (2012b) for the 2007 LFS. Magisterial districts, which are smaller than district councils, were mapped into district councils. See Bhorat et al. (2012b) for a more detailed account of the methodology used in mapping workers in the Labour Force Survey to the different area types.

${ }^{16}$ An exception is the September 2000 LFS, which shows that only 6 percent of the sample reported their income in bands.

${ }^{17}$ Note that given the differences in the time of introduction of the various sectoral minimum wage laws, the Post $_{t}$ variable is not uniform across sectors. Hence, the impact of the law on each sector is assessed separately.

${ }^{18}$ It is worth mentioning that the timing of the introduction of a minimum wage law may differ from the timing of the announcement of the law. The implication of the latter is that employers may have anticipated the introduction of minimum wages in a particular sector and responded to the legislation before the law was actually implemented or became binding. Anticipatory adjustments from employers would however bias us against finding significant impacts of the minimum wage laws on the sectors examined.

19 Dinkelman and Ranchhod (2012) use a similar measure constructed at the provincial level, whilst Hertz (2005) uses magisterial districts as the unit of analysis (Magisterial districts are smaller geographical areas than district councils. However, the use of magisterial districts as a unit of analysis yields very small sample sizes for some of the magisterial districts). Another application of such a relative wage gap measure in a difference-indifferences analysis of the impact of minimum wage legislation may be found in Lee (1999).

${ }^{20}$ Note that for the Retail sector, the wages of Managers were excluded when constructing the Gap $p_{j k}$ variable as these individuals generally earned above the minima in the pre-law period.

${ }^{21}$ Note that since the $\operatorname{Gap}_{j k}$ measure constructed is district-specific, this specification does not include district level effects.

${ }^{22}$ The date that the particular law was effective/binding as per the published minimum wage schedule is used as the date of introduction of the law. However, this may not be the same as the date of announcement of the law (see earlier footnote).

${ }^{23}$ Areas are demarcated by the Department of Labour for the purpose of setting minima on the basis of the average household income recorded for the municipal area on the basis of the 1996 Census. Generally, areas are categorized as follows:

A - Average income greater than R24,000 per annum; B - Average income between R12,000 and R24,000 per annum; C - Average income less than R12,000 per annum

${ }^{24}$ It is important to note that the Taxi sector minima do not apply to employees in the metered taxi sector.

${ }^{25}$ As previously noted, minimum wages are regularly updated for inflation. Therefore, an increase in wages observed across sectors may be reflective of the periodic increases in the legislated minima. 
${ }^{26}$ There are a number of other possible explanations for the lack of an obvious spike at the relevant minima for these sectors in South Africa. Firstly, the smoothing parameter used in the construction of the kernel density graphs may be obscuring a spike at the minimum. In order to control for the possibility that the bandwidth is too large and obscuring a spike, the bandwidth used in the construction of the Kernal plots was reduced to a fraction of the software default bandwidth (The bandwidth used in the plots presented here is the reduced bandwidth set to 0.02). Secondly, there may be an issue surrounding the reporting of wages in brackets versus point estimates in the Labour Force Survey. As noted above, around 12 to 16 percent of workers reported their wages in brackets in each wave of the survey. Estimation of the kernel density plots excluding wages that were reported in bands however, did not reveal a significant spike.

27 This is an approach taken in Dinkelman and Ranchhod (2012). They examine wages within a certain fraction (that is, between $\delta_{1}$ and $\mathrm{w}_{\mathrm{m}}$ where $\delta_{1}$ is 90 percent of the $\mathrm{w}_{\mathrm{m}}$ ) of the minimum wage (nearly compliant region) and examine shifts from the noncompliant region (below $\delta_{1}$ ) to the nearly compliant region as evidence of an incomplete wage adjustment in response to the law.

${ }^{28}$ As noted earlier, the sample in the employment analysis is all individuals of working age who are employed or searching for work, and who have no more than 12 years of schooling. This yields just under 500,000 observations across all 15 waves for the Retail, Domestic, Taxi, and Security sectors. For the Forestry sector, the sample is smaller (around 267,000 observations) due to the smaller size of the sample for these workers in the dataset.

${ }^{29}$ The results were estimated using a control group for each sector that excluded workers employed in other minimum wage affected sectors in each wave. However, there was no significant change in the results, that is, the impact of the minimum wage on employment was statistically insignificant (Results are not shown here but are available upon request).

${ }^{30}$ As noted earlier, the nominal wage results may be confounded by inflation. Therefore, only real wage impacts are analysed here.

${ }^{31}$ Note that a larger pre-law wage gap denotes lower wages in the pre-law period in the respective sector relative to the minimum introduced.

${ }^{32}$ Monthly wages are reported in the Labour Force Survey and could therefore be used as an outcome variable. These results are available upon request.

\section{Competing interests}

The IZA Journal of Labor \& Development is committed to the IZA Guiding Principles of Research Integrity. The authors declare that they have observed these principles.

\section{Acknowledgement}

The research, from which this paper emanates, was funded by the International Development Research Centre (IDRC). Responsible editor: David Lam

Received: 18 December 2012 Accepted: 19 December 2012

Published: 17 January 2013

\section{References}

Bhorat H (2000) Are minimum wage adjustments an effective mechanism for poverty alleviation? Some simulations for domestic and farm workers. Paper presented at the trade and international policy secretariat (TIPS) 2000 annual forum. Development Policy Research Unit, South Africa

Bhorat H, Kanbur R, Mayet N (2012a) A note on measuring the depth of minimum wage violation," Forthcoming in LABOUR: Review of Labour Economics and Industrial Relations, Vol 27 
Bhorat H, Kanbur R, Mayet N (2012b) Minimum wage violation in South Africa. Int Labour Rev 151:277-287 Bhorat H, Kanbur R, Mayet N (2012c) Estimating the causal effect of enforcement on minimum wage compliance: the case of South Africa. Rev Dev Econ 16:608-623

Bhorat H, Kanbur R, Stanwix B (2011) Estimating the impact of minimum wages on employment, wages and Non-wage benefits: the case of agriculture in South Africa. Developing policy research unit working paper series WP 12/149. Development Policy Research Unit, University of Cape Town, South Africa, Available from: http://www.dpru.uct.ac $\mathrm{za} / ? \mathrm{q}=$ node $/ 277$

Branson N (2009) Re-weighting the OHS and LFS national household survey data to create a consistent series over time. A Cross Entropy Estimation Approach., SALDRU/DataFirst Working Paper Series No.38. Available from: http:// www.saldru.uct.ac.za/home/index.php?/Researchers/nicola-branson. (Accessed 7 January 2013)

Brown C, Gilroy C, Kohen A (1982) The effect of the minimum wage on employment and unemployment. J Econ Lit 20:487-528

Card D (1992) Do minimum wages reduce employment? a case study of California, 1987-1989. Indust Labour Relat Rev 46:38-54

Card D, Krueger A (1994) Minimum wages and employment: a case study of the fast-food industry in New Jersey and Pennsylvania. American Economic Review, Pennsylvania, p 84

Card D, Krueger A (1995) Myth and measurement: The New economics of the minimum wage. Princeton University Press, Princeton, NJ

Charles B, Gilroy C, Kohen A (1983) Time-Series Evidence of the Effect of the Minimum Wage on Youth Employment and Unemployment. J Hum Resour 18(1):3-31, Available from: http://links.jstor.org/sici?sici=0022166X\%28198324\% 2918\%3А1\%3C3\%3АTEOTEO\%3E2.0.CO\%3B2-Q

Conradie B (2004) Wages and wage elasticities for wine and table grapes in South Africa. Centre for Social Science Research, Working Paper 90, University of Cape Town, South Africa, Available from: http://www.cssr.uct.ac.za

Department of Labour (1999) Government Notice No. 622. Sectoral Determination 1: Contract Cleaning Sector, South Africa., Available from: http://www.labour.gov.za/legislation/sectoral-determinations/sectoral-determination-1contract-cleaning-sector

DiNardo J, Fortin N, Lemieux T (1996) Labour market institutions and the distribution of wages, 1973-1992: a semiparametric analysis. Econometrica 64:1001-1044

Dinkelman T, Ranchhod V (2012) Evidence on the impact of minimum wage laws in an informal sector: domestic workers in South Africa. J Develop Econ Elsevier 99:27-45

Gindling TH, Terrell K (2005) The effect of minimum wages on actual wages in formal and informal sectors in Costa Rica. World Develop Elsevier 33:1905-1921

Gindling TH, Terrell K (2007) The effects of multiple minimum wages throughout the labour market: the case of Costa Rica. Labour Econ 14:485-511

Hamermesh D (1993) Labour demand. Princeton University Press, Princeton N.

Hamermesh D (2002) International Labor Economics. J Labor Econ 20(4):709-732

Hertz T (2002a) Can Wage Cuts Reduce Poverty? Simulation Evidence from South Africa

Hertz T (2002b) Forecasting the Effects of Pending Minimum Wage Legislation On Poverty in South Africa

Hertz T (2005) "The effect of minimum wages on the employment and earnings of South Africa's domestic service workers,". Working Paper No. 2005-04, Department of Economics, American University, USA

Hertz T (2006) "Have minimum wages benefited South Africa's domestic service workers?" Working paper. American University, Department of Economics

Katz L, Krueger A (1992) The effect of the minimum wage on the fast-food industry. Indust Labour Relat Rev 46:6-21 Lee D (1999) "Wage Inequality in the United States During the 1980s: Rising Dispersion or Falling Minimum Wage?". Q J Econ 114:977-1023

Lester A (1947) "Marginalism, minimum wages, and labour markets,". The American Economic Review, USA, p 37

Lester A (1960) Employment effects of minimum wages. Indust Labour Relat Rev 13:254-264

Lester A (1967) The economics of labour, 2nd edn. Macmillan, New York

Machin S, Manning A (1994) The effects of minimum wages on wage dispersion and employment: evidence from the U.K. Indust Labour Relat Rev 47:319-329

Maloney W, Nuñez J (2004) Measuring the impact of minimum wages: evidence from Latin America'. In: Heckman J, Pagès C (eds) Law and employment. Lessons from Latin America and the Caribbean. NBER, Cambridge, MA

Murray J, Van Walbeek C (2007) "Impact of the sectoral determination for farm workers in the South African sugar industry: case study of the Kwazulu-Natal north and south coasts,". Centre for Social Science Research, Working Paper 181, University of Cape Town, South Africa, Available at: http://www.cssr.uct.ac.za

Neumark D, Wascher W (1992) Employment Effects of Minimum and Subminimum Wages: Panel Data on State Minimum Wage Laws. Ind Labor Relat Rev 46(1):55-81

Neumark D, Wascher W (2007) "Minimum wages and employment,". IZA discussion papers 2570. Institute for the Study of Labour (IZA), Bonn

Starr GF (1981) Minimum Wage Fixing: An International Review of Practices and Problems. Int Labour Organ (ILO)

Stigler G (1946) "The economics of minimum wage legislation,". The American Economic Review, USA, p 36

doi:10.1186/2193-9020-2-1

Cite this article as: Bhorat et al:: The impact of sectoral minimum wage laws on employment, wages, and hours of work in South Africa. IZA Journal of Labor \& Development 2013 2:1. 